HARRIET BUSH

\title{
TAX AVOIDANCE IN NEW ZEALAND: IN SEARCH OF PRINCIPLES
}

\author{
LLM RESEARCH PAPER \\ LAWS 516: TAXATION, INTERNATIONAL AND DOMESTIC
}

FACULTY OF LAW

te whare Wánanga o te úoko o te ika a máui

2013 


\section{Contents}

Introduction ..

II The Presence of Principles in Judicial Reasoning

A Jurisprudential Theories: the Role of Principles

B The Application of Moral Principles to Tax Law: Evidence from Case Law 8

$A$ The Nature of Section BG 1

B The Parliamentary Contemplation Test.

$C$ The Effect of the Parliamentary Contemplation Test upon when s BG 1 Will

Be a Hard Case 18

10 IV What Are the Possible Principles in Tax Law?

A Tax Should Apply Uniformly to All Cases That are Economically Similar.20

B Taxpayers Are Entitled to Structure Their Affairs So As to Pay No More Tax

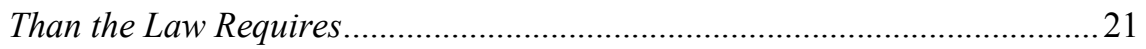

C Are the Antecedent Principles Dworkinian Principles? ..............................23

A The Duke of Westminster Principle

B The GAAR Should Not Deprive Taxpayers of Tax Beneficial Choices.........25

C The Need for Commercial Certainty

$D$ The Scope of the GAAR Must Be Ascertained through Looking at the

VI The Role of Principles in Ascertaining Parliament's Contemplation

A The Application of the Parliamentary Contemplation Test in Ben Nevis ...31

B Had Artificiality and Contrivance Previously Been Held to Be Signs of Tax Avoidance?

C The Application of the Parliamentary Contemplation Test Post-Ben Nevis

VII Parliament's Contemplation: Should Principles Help? 36

A A Jurisprudential Approach.

$B$ The Argument against Reliance on the First Principle 37 
VIII Conclusion

IX Bibliography .42

\section{Abstract}

5 This paper analyses the judicial application of New Zealand's general antitax avoidance rule contained in s BG 1 of the Income Tax Act 2007 in the light of three $20^{\text {th }}$ Century jurisprudential theories of legal reasoning. It focuses specifically on the role of moral principles in the process of judicial decision-making and explores whether existing case law on the avoidance

10 provision can be seen as supporting the hypothesis that judges apply moral principles when reaching decisions. Following the test laid down for tax avoidance in the Supreme Court's decision in Ben Nevis Ventures Ltd \& Others v Commissioner of Inland Revenue, the paper concludes that judges have the ability, in some cases, to reach their decision about whether there

15 has been tax avoidance by applying the moral principle that tax should apply uniformly to all cases that are economically similar.

\section{Word Length}

The length of this paper (excluding table of contents, abstract, footnotes and bibliography) comprises 14,980 words

\section{Subjects and Topics}

New Zealand General Anti-Avoidance Rule

Income Tax Act 2007

Tax Avoidance

Judicial Reasoning

25 Moral Principles in Law 


\section{Tax Avoidance in New Zealand: in Search of Principles}

\section{Introduction}

Large scale tax avoidance is becoming an increasingly prevalent problem for many countries. For example, HM Revenue and Customs department 5 estimated that tax avoidance cost the United Kingdom $£ 5$ billion in $2012 .{ }^{1}$ Most countries have sought to combat tax avoidance by enacting both specific and general anti-avoidance rules. New Zealand's general antiavoidance rule is found in S BG 1 of the Income Tax Act 2007. The application of this section and its predecessors has frequently caused

10 difficulty. For example, judges have often been criticised for using this section to strike at tax arrangements that they do not like the feel of, ${ }^{2}$ or for applying the section in a way which goes beyond their judicial role to interpret the law. ${ }^{3}$

This paper seeks to analyse the judicial interpretation of New Zealand's

15 anti-avoidance provision in the light of the leading $20^{\text {th }}$ Century jurisprudential theories and of their application to judicial decision-making. It will focus specifically on the stance that each of these theories takes on the presence and importance of moral principles in judicial reasoning, and also assess which theory most accurately reflects the courts' interpretation of $\mathrm{s}$ BG 1 .

The paper will first set out Ronald Dworkin's theory of law and contrast it with two different theories of judicial reasoning; the first offered by HLA Hart and the second by the critical legal studies movement. Then it will look at whether judges explicitly reference moral principles in tax judgments and

25 what they say about the relevance of moral principles to judicial reasoning. It will then compare the judgments to several judges' extrajudicial writings about the process of judicial reasoning. The section will conclude by adopting the approach to judicial reasoning supported in the secondary literature; that is, that judges do use principles in decision-making, but only 30 in some cases, and that the use of principles does not limit judicial discretion.

\footnotetext{
1 HMRC "Tackling Tax Avoidance" (Issue Briefing, London, September 2012). This amount accounts for $14 \%$ of the gap between the tax that is owned and the tax that is collected, which is estimated to be $£ 35$ billion.

2 Eugene Trombitas "Comment: Trinity Exposed: Does the Emperor Really Have No Clothes or is He Wearing an Unusual Silver Rugby Jersey? The Latest News from the GAAR Front" (2007) 13 NZJTLP 583 at 591.

${ }^{3}$ See the statement of Lord Donovan in Mangin v Commissioner of Inland Revenue [1971] NZLR $591(\mathrm{PC})$ at 597.
} 
Section two will focus more specifically on s BG 1. It will assess whether this is a provision which gives judges the scope for to apply principles when applying the section in their judgments and why this might be so. Section three will then examine two principles that scholars identify as underlying tax law and section four will look at common arguments made in relation to the provision and at whether these arguments reflect either of the identified principles. Section five will discuss whether there is still room for judges to be guided by moral principles when applying the avoidance provision following the Supreme Court's first decision concerning s BG 1 in the 2008 case Ben Nevis Forestry Ventures Ltd \& Others v Commissioner of Inland Revenue. ${ }^{4}$ Finally, the paper will consider whether it is legitimate for judges to rely on moral principles in tax avoidance cases.

\section{The Presence of Principles in Judicial Reasoning}

\section{A Jurisprudential Theories: the Role of Principles}

15 Ronald Dworkin is often credited with making the morality of law something with which $20^{\text {th }}$ century jurisprudence had to deal. Before Dworkin, the most widely accepted form of jurisprudential thought throughout the $20^{\text {th }}$ century had been legal positivism. This theory of law holds that law does not necessarily have a moral element. Rather, legal

20 thought and legal obligations can be separated and are distinct from morality. The theory of law laid down by Dworkin challenged this separation of law and morality. Dworkin argued that law and morality were intertwined because of the presence of moral principles in law. According to Dworkin's theory, as well as the legal rules which are found in statute and

25 common law doctrines, the legal system contains moral principles of justice and fairness. ${ }^{5}$ Dworkin addressed the impact of these principles on judicial decision-making when he laid out his process of reasoning. He argued that when a judge decides a case the judge must first identify possible interpretations of the law that fit existing law; that is, the interpretations of

30 the statute that are consistent with both the words of the statute and with existing precedent. If there is more than one possible interpretation of this existing legal practice, the judge must then identify the interpretation of the law that best justifies the law as a whole in the light of principles of political

\footnotetext{
${ }^{4}$ Ben Nevis Forestry Ventures Ltd \& Others v Commissioner of Inland Revenue [2008] NZSC 115, [2009] 2 NZLR 289.

5 Ronald Dworkin "The Model of Rules" (1967) 35 The University of Chicago Law Review 14 at 41.
} 
morality. This interpretation of the law will provide the right answer to the case. $^{6}$

Dworkin described legal principles as fundamentally different from legal rules. Legal rules, he said, are laid down in statue or by the common law and are therefore either valid or invalid, and either apply conclusively in a given case or do not. Principles, on the other hand, do not come from case law or statute, but develop over time because the legal profession and the public consider them to be appropriate. ${ }^{7}$ Principles do not necessitate a particular resolution to a case but point towards, or argue for, deciding a case in one way or another. Legal principles are general notions of justice and fairness that are broad and unspecific. ${ }^{8}$ For instance, one example of a principle that Dworkin gives is the maxim that "no man may profit from his own wrong." When there is more than one principle underlying a particular statute or body of precedent then the judge is legally bound to weigh the conflicting principles against each other and assess which principle is stronger in order to come to the right answer to the case. Although judges may do this with reference to their subjective values, Dworkin maintained that, because judges are bound to apply any competing relevant principles, they do not have strong discretion in the way that he understood positivist theories of law to incorporate discretion. ${ }^{10}$

Dworkin's theory of law is largely based on a critique of the theory developed by leading positivist scholar, HLA Hart. ${ }^{11}$ Hart's theory of law is based upon the existence of what he identified as the rule of recognition. The rule of recognition is the ultimate rule of the legal system because it provides the criteria for the validity of all of the other rules of the system. A law will be valid if it is passed in accordance with the rule of recognition. ${ }^{12}$

\footnotetext{
${ }^{6}$ Ronald Dworkin Law's Empire (Harvard University Press, Cambridge, 1986) at 254-258. This book contains an expanded version of the theory first posited in "The Model of Rules", above n 5.

${ }^{7}$ Ronald Dworkin Taking Rights Seriously (Harvard University Press, Cambridge, 1978) at 40.

${ }^{8}$ Dworkin "The Model of Rules", above n 5, at 25-26.

9 Dworkin "The Model of Rules", above n 5, at 23-24 citing the case of Riggs v Palmer 22 NE 188 (NY 1889).

${ }^{10}$ Dworkin "The Model of Rules", above n 5, at 27- 34. By strong discretion Dworkin was referring to the idea that judges must look beyond the law and apply extra-legal standards to resolve a case.

${ }^{11}$ Dworkin's critique of Hart changed substantially over time. In "The Model of Rules", Dworkin argued that the main deficiency in Hart's theory was that it could not account for the existence of legal principles. (At 22). In Law's Empire, Dworkin argued that positivism cannot explain theoretical disagreement about the law; that is, when judges dispute what must take place in the legal system before a proposition of law is true. This is a result of a plain-fact approach to law. (At 4-6). For an in-depth discussion of Dworkin's theory of law, see Scott J Shapiro “The 'Hart-Dworkin' Debate: A Short Guide for the Perplexed" (2007) University of Michigan Public Law and Legal Theory Working Paper No. 77.

${ }^{12}$ HLA Hart The Concept of Law (2 ${ }^{\text {nd }}$ ed, Clarendon Press, Oxford, 1994) at 81-99.
} 
Hart argued that the laws identified by the rule of recognition have open textures as a result of the open texture of language. Each law has a core and a penumbra. It is certain that the law will apply to fact scenarios within the core of the law because these scenarios will clearly fit the within the general language used in the relevant section of the statute. However, within the penumbra of the law it may be uncertain whether the law applies. ${ }^{13}$ In such cases, Hart argued that the law is fundamentally incomplete. When a judge decides such a case, the judge is not constrained by any legal rules; rather the judge is unregulated and must exercise discretion. ${ }^{14}$ Hart still maintained that in exercising discretion the judge must not act arbitrarily and must have general reasons to justify his decision. Where Hart's theory differs from Dworkin's is that it holds that although judges may appeal to principles to decide cases, they are not legally obliged to do so. Therefore when they do rely on principles, they are reaching beyond the law. ${ }^{15}$ Further, the use of principles in judicial reasoning is only a matter of social fact. This means that at any time judges are free to stop using principles to guide their decisions. $^{16}$

The final theory of law that is relevant to the application of principles in the process of judicial reasoning is critical legal studies. Critical legal studies developed as a prominent theory of law in the 1970s. Its origin is usually traced back to American legal realism. ${ }^{17}$ Like Hart's theory of law, critical legal theories leave room for the presence of moral principles in law. However, like Hart they do not attach importance to moral principles in limiting discretion in judicial decision-making. This is because critical legal scholars see the law as indeterminate. Theories of radical indeterminacy argue that the law is indeterminate in nearly all cases because every area of law embodies conflicting principles and counter-principles that cannot be balanced or reconciled with one another. ${ }^{18}$ The result of these inconsistencies is that judges have the ability to decide all cases according to their own preferences. This argument differs from Hart's theory, which holds that judges only have discretion in a limited number of cases at the margins or penumbra of a law. The belief of critical legal scholars that the law is indeterminate is a part of the critical legal studies' criticism of law as

\footnotetext{
${ }^{13}$ HLA Hart The Concept of Law, above $\mathrm{n}$ 12, at 123.

${ }^{14}$ HLA Hart The Concept of Law, above $\mathrm{n} 12$ at 252-255.

${ }^{15}$ HLA Hart The Concept of Law, above n 12, at 273-275.

${ }^{16}$ HLA Hart The Concept of Law, above $\mathrm{n}$ 12, at 250-260.

17 See for example Gary Minda "Jurisprudence at Century's End" (1993) 43 Journal of Legal Education 27 at 39-46; Duncan Kennedy and Karl Klare "Biography of Critical Legal Studies" (1984) 94 Yale Law Journal 461; Roberto Mangabeira Unger "The Critical Legal Studies Movement” (1983) 96 Harvard Law Review 561.

${ }^{18}$ Ken Kress "Legal Indeterminacy” (1989) 77 CLR 283 at 288 and 302.
} 
an institution that is geared to favour the wealthy elite. Critical legal scholars argue that judicial discretion creates the opportunity for judges to further perpetuate the imbalance of power created by the legal system in the hands of the elite by deciding cases in accordance with their own beliefs and values.

Jack Balkin critiqued Dworkin's theory of judicial interpretation through the lens of critical legal studies. He argued that even if a judge feels subjectively constrained to apply moral principles when deciding a case, in coming to a decision based on the principles that the judge considers best justify the law, the judge is simply writing his or her own ideological preferences into the law. ${ }^{19}$ Balkin argued that a judge is: $:^{20}$

So thoroughly invested in her own world view that it always seems to her that the best moral/political theory that fits the largest number of cases is the theory that comports with her ideological convictions.

This is made possible, Balkin argued, by the fact that tension between legal doctrines or principles can be found within every individual judgment or statute. ${ }^{21}$ A 2005 study of judicial voting data of the United States Courts of Appeal in the light of Dworkin's theory of interpretation found that the presence of principles and an increasing amount of relevant precedent do not eliminate judicial discretion. In fact, the authors concluded that as the number of prior decisions in a given area of law increased, individual judges appeared to be more able to decide the case based on their ideological preferences. $^{22}$ These findings support Balkin's view of judicial discretion and the effect of precedent.

The divergence in views between the three different jurisprudential theories means that, in order to assess which theory presents the best interpretation of judicial application of the avoidance provision, it is important not only to assess whether principles are used in judicial decisionmaking but also, if principles are used, to look at the effect of the principles. Specifically, it is necessary to analyse whether the presence of principles can be seen as equating to an absence of judicial discretion, as Dworkin asserts, or rather to a way for the judge to come to a decision not by applying law but by applying his or her own value system. Additionally, because Hart argues that judges are not legally obliged to apply principles, it is also

19 JM Balkin "Taking Ideology Seriously: Ronald Dworkin and the CLS Critique" (1987) 55 UMKC Law Review 392 at 422.

${ }^{20}$ Balkin, above n 19, at 423 .

${ }^{21}$ Balkin, above $\mathrm{n} 19$, at 413 .

22 Stefanie A Lindquist and Frank B Cross "Empirically Testing Dworkin's Chain Novel Theory: Studying the Path of Precedent” (2005) 80 NYUL Rev 1156. 
necessary to evaluate whether judges apply moral principles as a matter of law, or whether the application of principles is one available technique in judicial decision-making that a judge may, but is not required to, use.

$B$ The Application of Moral Principles to Tax Law: Evidence from Case

\section{Law}

To evaluate which theory of law presents the most accurate description of the process of judicial decision-making, it is of course necessary to start by looking at the judgments themselves. This section will therefore explore whether tax judgments in general make any explicit reference to moral principles.

The answer suggested by a preliminary look at the case law is that judges do not apply moral principles. The cases show that not only do judges say that they are not applying moral principles, they often emphasise that there is no place for moral judgments in tax law. For example, in Mangin $v$

15 Commissioner of Inland Revenue, the court said that "moral precepts are not appropriate to the application of revenue statutes." 23 Similarly, in Miller $v$ Commissioner of Inland Revenue the Privy Council cautioned against the use of the word impropriety in relation to tax avoidance arrangements. Their Lordships said that this suggested a moral judgment that they thought "inappropriate" and further that such a judgment had "been consistently repudiated in cases on tax avoidance schemes in England and New Zealand." 24 More recently, the Supreme Court in Ben Nevis reaffirmed this approach. The majority stated that when applying s BG 1 to a given scenario, courts should not be distracted by "intuitive subjective impressions of ... morality." 25

A similar approach to the irrelevance of morality can be seen in United States decisions. For example, Learned Hand $\mathrm{J}$ said in the case of Commissioner $v$ Newman: ${ }^{26}$

There is nothing sinister in so arranging one's affairs as to keep taxes as low as possible. Everybody does so, rich or poor, and all do right; for nobody owes any public duty to pay more than the law demands. To demand more in the name or morals is mere cant.

These cases are part of a long line of authority which says that tax avoidance is not immoral, because there is no moral obligation for people to

${ }^{23}$ Mangin v Commissioner of Inland Revenue [1971] NZLR 591 (PC) at 594.

${ }^{24}$ Miller v Commissioner of Inland Revenue [2001] UKPC 17, [2001] 3 NZLR 316 at [9].

${ }^{25}$ Ben Nevis, above n 4, at [102].

${ }^{26}$ Commissioner v Newman 159 F $2 d 848\left(2^{\text {nd }}\right.$ Cir 1947) at 850-851. 
arrange their affairs in a way that enables the tax department to take as much tax as possible. ${ }^{27}$ This approach to tax was discussed in detail by Zoe Prebble and John Prebble. They argue that this stems from several unsubstantiated assumptions. The first is the idea that there is a moral 5 entitlement to pre-tax income. ${ }^{28}$ The second assumption is that tax avoidance is not harmful. ${ }^{29}$ Thirdly, tax avoidance cannot be immoral because tax is not something that exists outside of law, so tax avoidance could only be immoral if it were also illegal. ${ }^{30}$ The final assumption is that the morality of an act can be determined independently of law. ${ }^{31}$ After discussing and rejecting these four assumptions the authors conclude that tax evasion is morally wrong by virtue of both its contents and of its legal status. Because of the fact that tax avoidance is almost factually indistinguishable from tax evasion, they argue that tax avoidance should similarly be seen as immoral. ${ }^{32}$

15 There are several cases in which judges have adopted the view endorsed by Zoe Prebble and John Prebble that tax avoidance is immoral. For example, in both Latilla $v$ Commissioner of Inland Revenue and Ensign Tankers Ltd $v$ Stoakes the court was critical of the significant negative effects of tax avoidance on other taxpayers, suggesting that tax avoiders unfairly circumvent their duty to contribute to society. ${ }^{33}$ However, the strong statements that morality is irrelevant in some of the most often-cited judgments on tax avoidance provide a strong indication to lower court judges that it is not appropriate for their decisions to be influenced by morality. Therefore, direct statements in case law indicate that moral principles do not play a part in judicial decision-making in tax avoidance cases.

D The Application of Moral Principles to Tax Law: What Judges Say Extra Judicially

30 Direct statements in the case law about the irrelevance of morality are an important starting point when assessing whether there is room for the application of moral principles in tax law. However, several legal theorists indicate that judicial pronouncements in cases should be treated with care.

${ }^{27}$ See for example Lord Clyde's famous dicta in Ayrshire Pullman Motor Servs and DM Ritchie v CIR [1929] 14 TC 754 (HL) at 763-764.

${ }^{28}$ Zoe Prebble and John Prebble "The Morality of Tax Avoidance" (2010) 43 Creighton L Rev 694 at 719-721.

${ }^{29}$ Zoe Prebble and John Prebble, above n 28, at 722-726.

${ }^{30}$ Zoe Prebble and John Prebble, above n 28, at 728.

${ }^{31}$ Zoe Prebble and John Prebble, above n 28, at 732-734.

${ }^{32}$ Zoe Prebble and John Prebble, above n 28, at 737.

33 See Latilla $v$ Commissioner of Inland Revenue [1943] 1 All ER 265 (HL); Ensign Tankers Ltd v Stoakes [1992] 2 All ER 275 (HL), discussed below at [VII]. 
These theorists are sceptical about the value of looking only at the judgment when trying to ascertain how a case has been decided. This is because a realist or pragmatic approach to judicial decision-making holds that a judge does not always explain the real reasons for his or her decision in the actual 5 judgment. ${ }^{34}$ This is a result of the role that judges have in our society. A judge's role is to be an unbiased interpreter of the law laid down by Parliament. Judges therefore risk losing their legitimacy if they are seen to decide cases with reference to non-legal factors such as their own preferences or ideologies. ${ }^{35}$ Therefore, even if a judge has reached a decision that was not dictated solely by law, or the judge's decision has been influenced by his or her own feelings about the case, the judge will not admit this in the judgment itself.

Like realist scholars, Dworkin did not treat what is written in a judgment as the whole story. According to his theory, the principles of political morality upon which judges rely are not necessarily explicitly referred to in judgments; rather they may simply be latent in the relevant area of law. It is the job of the scholar to look at the existing law and precedent to extract the principles implicit in judgments. This is in part because judicial application of moral principles may be either conscious or sub-conscious. ${ }^{36}$

20 Finally, tax practitioners and academics commenting on tax avoidance decisions have often been critical about how judges have decided that there was tax avoidance in a particular case. For example, Eugene Trombitas argued that the question of whether there was tax avoidance would often turn on whether the court liked the transaction or not. ${ }^{37}$

25 The above sceptical approaches suggest that it is not sufficient simply to take the statements from judges in their judgments that they have not applied moral principles at face value as the answer to the question of whether judges apply principles in tax cases. Therefore, this section of the essay will look at whether the extrajudicial writings of judges confirm or contradict the claims in judgments that judges do not apply moral principles in reaching their decisions.

A survey of extrajudicial writing contradicts the claims in judgments that moral principles are irrelevant to judicial reasoning. Instead they provide preliminary support for the hypothesis that judges may apply principles

\footnotetext{
34 See James Allan "Statutory Interpretation and the Courts" (1999) 18 New Zealand University Law Review 439 at 439; Brien Leiter "Legal Realism" in Dennis M Patterson (ed) A Companion to Law and Legal Philosophy (Blackwell Publishers, Oxford 1996) 261 at 269-270.

${ }^{35}$ Kress, above n 18, at 285; Michael Tushnet "Following the Rules Laid Down: A Critique of Interpretivism and Neutral Principles" (1983) 96 Harvard Law Review 781 at 781-782.

${ }^{36}$ Dworkin Taking Rights Seriously, above n 7, at 377-379.

${ }^{37}$ Trombitas, above $\mathrm{n}$, at 597.
} 
when reaching decisions. The first jurist whose writing supports this theory is Sir Ivor Richardson. Writing in 1967 about the interpretation of tax statutes, Sir Ivor said: $:^{38}$

Judicial attitudes and their effect on the interpretation of revenue legislation hinge[d] on ... the background and susceptibilities of the particular judge and the scope for divergent interpretations of the provisions in question.

Although this statement alone seems to point towards unfettered judicial discretion, read in the context of two later articles, this statement can be seen as expressing the view that judges are influenced by underlying values when applying the law. Richardson's discussion in an essay in 1985 can be read as supporting the argument that judges are influenced by principles. There he said: ${ }^{39}$

In a relatively small number of cases the legal answer is not automatic ... In such cases what course is followed reflects a value judgment on the judge's part. The judicial answer will depend upon the conscious or unconscious assessment of the underlying values involved. The judge is engaged in a balancing exercise.

Similarly, in the specific context of the anti-avoidance rule Sir Ivor noted that uncertainty arose from differing judicial perspectives on morality. The interpretative approach taken, he concluded, inevitably depended on judicial attitudes and on the perspectives that judges had of community values. ${ }^{40}$

Another example of judicial acknowledgement of principles is found in the work Sir Edmund Thomas, who was a member of the New Zealand Court of Appeal from 1995 to 2001. In his book about judicial process, Thomas said that legal principles were of central importance in judicial reasoning. ${ }^{41}$ In a similar article, Thomas considered the direction in Ben Nevis that judges should not be distracted by subjective impressions of the morality of an arrangement. In response to this direction he said that he was not suggesting that judges should incorporate subjective impressions of morality, rather that judges should indicate the value judgment on which their decision was based "in pursuit of the need for transparency in judicial

\footnotetext{
${ }^{38}$ ILM Richardson "Attitudes to Income Tax Avoidance" (1967) 30 NZJPA 1 at 16.

${ }^{39}$ ILM Richardson "The Role of Judges as Policy Makers” (1985) 15 VUWLR 46 at 46.

40 Ivor Richardson "Reducing Tax Avoidance by Changing Structures, Processes and Drafting" in Graeme Stuart Cooper (ed) Tax Avoidance and the Rule of Law (IBDF Publications and the Australian Tax Research Foundation, Amsterdam, 1997) 327 at 329330.

41 EW Thomas The Judicial Process: Realism, Pragmatism, Practical Reasoning and Principles (Cambridge University Press, Cambridge, 2005) at 118 - 226 and 339.
} 
adjudication." ${ }^{42}$ Therefore, although Thomas did not think that judges should be influenced by vague moral impressions, he nevertheless considered that a value judgment, or invocation of a principle, was part of the decisionmaking process.

5 The extrajudicial work of two respected Australian judges is also enlightening. Justice Hill, of the Federal Court of Australia, expressed a similar attitude to judicial decision-making. He considered that the application of statutory interpretation to a particular statute and that statute's application to a set of facts often left the judge "discretion to reach a conclusion which he or she perceive[d] to be just."43

Justice Kirby, of the Australian High Court, in reflecting upon the moment of decision in judicial decision making, concluded that: ${ }^{44}$

Sometimes the decision may emerge, with pure logic, from the application of a clear and settled legal principle to simple and uncontested facts. But... often the applicable principle is not clear. The Act of Parliament is unclear. The facts are disputed and uncertain. Choices must be made.

What is immediately apparent from these examples is that although these judges accept that there is room in decision-making for them to apply underlying community values or principles, none of the judges view the existence of principles as eliminating judicial discretion in the way that Dworkin describes. That is, although Dworkin sees the presence of principles as creating a binding obligation on judges to come to a decision

25 based on moral principles of justice and fairness, and believes that the assessment of principles will lead the judge to the right answer to the case, judges view the application of principles and community values as a complex task often involving a careful balancing exercise and considered use of their discretion.

30 In Dworkin's view, a theory of law such as Hart's that does not incorporate principles as part of the law allows judges to decide cases not according to any particular standards but by reaching beyond the law and deciding cases in any way they want. If judges are bound to apply principles, however, Dworkin argued that this would eliminate discretion in this

${ }^{42}$ EW Thomas "The Evolution from Form to Substance in Tax Law: the Demise of the Dysfunctional 'Metwand"” (2011) 19 Waikato L Rev 17 at 23.

${ }^{43}$ DG Hill "How is Tax Law to be Understood by Courts?" (2001) The Tax Specialist 226 at 233.

${ }^{44}$ Hon Justice Michael Kirby “Judging: Reflecting on the Moment of Decision" (paper presented at the $5^{\text {th }}$ National Conference on Reasoning and Decision-Making, Wagga Wagga, 4 December 1998). 
stronger sense. However, Dworkin does admit that even when principles are included, there remains an element of discretion, because when a judge decides between competing principles the judge must exercise judgment. ${ }^{45}$

Dworkin's approach to discretion has been criticised as "based on a peculiarly narrow notion of what it means to have discretion to make a choice" ${ }^{46}$ and inconsistent with our ordinary understanding or judicial responsibility for opinion. ${ }^{47}$

These articles demonstrate a more pragmatic approach to the effect of principles on judicial decision-making than Dworkin's theory does. The judges indicate that ultimately the question of which principle to apply will come down to a value judgment on that judge's part and further, that it is this room to choose between competing principles or values that is the type of discretion that is important. The articles also seem to endorse Hart's approach to decision-making, that not every case will leave room for the application of principles. Rather, principles might be appealed to when there is a gap between the law as written in the statute and the answer to how the law should apply in the case, or, as Sir Ivor Richardson said, when the answer is not automatic. Finally, these statements show that while the judges accept an element of discretion, the principles or values they apply in hard cases will be informed by community values rather than their subjective feelings.

Because of the scepticism shown by legal theorists towards the accuracy of pronouncements in case law, this paper adopts the comments of judges concerning judicial reasoning in extrajudicial writings as the framework for analysing the application of s BG 1. Extrajudicial writings support Hart's proposition that it is only in some cases that judges have the ability to decide according to principle. Therefore, this paper also adopts the view that it is only in some cases that there is room for judges to use principles. This means that it is necessary to assess in which avoidance cases judges will have the ability to apply principles and why this is so. In other words, before cases are analysed for the presence of principles, it must be established when and why applying s BG 1 will amount to a hard case where a judge may rely upon principles.

\footnotetext{
${ }^{45}$ Dworkin Law's Empire, above n 6, at 260-267.

${ }^{46}$ Kent Greenwalt "Discretion and Judicial Decision: the Elusive Quest for the Fetters that Bind Judges" (1975) 75 Columbia Law Review 359 at 361.

${ }^{47}$ Greenwalt above n 46, at 361.
} 


\section{The General Anti-Avoidance Rule Landscape}

In order to evaluate which avoidance decisions will allow judges to apply principles, the features of tax avoidance and the scope of s BG 1 must first be laid out. Tax avoidance may be described as "contriving transactions ... so as to reduce the tax that would otherwise be payable according to be the policy of the taxing provision in question." 48 It results in narrowing the tax base and undermining the efficiency, equity and integrity of the tax system. ${ }^{49}$ Although New Zealand has had a GAAR that applies to income tax since $1891,{ }^{50}$ the first reported case applying the section was not until $1938 .{ }^{51}$ The avoidance provision is contained in s BG 1 of the Income Tax Act 2007. This section states that a tax avoidance arrangement is void as against the Commissioner for Income Tax purposes. Tax avoidance arrangement is defined as: ${ }^{52}$

an arrangement, whether entered into by the person affected by the arrangement or by another person, that directly or indirectly-

(a) has tax avoidance as its purpose or effect; or

(b) has tax avoidance as 1 of its purposes or effects, whether or not any other purpose or effect is referable to ordinary business or family dealings, if the tax avoidance purpose or effect is not merely incidental.

Tax avoidance includes: ${ }^{53}$

(a) directly or indirectly altering the incidence of any income tax:

(b) directly or indirectly relieving a person from liability to pay income tax or from a potential or prospective liability to future income tax:

(c) directly or indirectly avoiding, postponing, or reducing any liability to income tax or any potential or prospective liability to future income tax.

When an arrangement is declared void as a tax avoidance arrangement, the Commissioner has the power to adjust the taxpayer's taxable income in a

${ }^{48}$ Rebecca Prebble and John Prebble "Does the Use of General Anti-Avoidance Rules to Combat Tax Avoidance Breach Principles of the Rule of Law? A Comparative Study" (2010) 55 Saint Louis University Law Journal 21 at 22.

${ }^{49}$ Eberson, above n 84, at 267.

${ }^{50}$ Land and Income Tax Assessment Act 1891.

${ }^{51}$ Timaru Herald Co Ltd v Commissioner of Taxes [1938] NZLR 978 (CA).

${ }^{52}$ Income Tax Act 2007, s YA 1.

${ }^{53}$ Income Tax Act 2007, s YA 1. 
way that the Commissioner thinks is appropriate in order to counteract the tax avoidance advantage gained. ${ }^{54}$

\section{$A$ The Nature of Section $B G 1$}

Several articles concerning the GAAR suggest that the GAAR may be different

5 from other laws because it allows judges to decide whether the GAAR applies according to underlying principles in every case. They argue that this is because the GAAR does not contain a core where it is certain that it applies to fact scenarios, but rather may be only penumbra. ${ }^{55}$ For example, Michael Littlewood argued that: ${ }^{56}$

Most legal concepts have a more or less solid core and are disputed only at the margins... But the idea of tax avoidance has no core... for there is no such thing as a non-contestable case of tax avoidance.

However, it is questionable whether this approach is correct.

One explanation for the uncertainty that is involved in the application of this section is the approach that was traditionally taken to its interpretation by the courts. The courts have long accepted that a literal interpretation of the section would result in it catching transactions at which it was obviously not aimed. ${ }^{57}$ This is because, if its meaning is ascertained solely from the

20 words of the avoidance provision, it would extend to any transaction that alters the incidence of tax payable. As Woodhouse J said, "nearly all disposition of property or income must carry with them some consequential effect upon income tax liabilities." ${ }^{, 58}$ These problems resulted in courts trying to provide ways of restricting the section so that it had a desirable, reasonable and predictable ambit by placing judicial glosses on the words of the statute to limit its scope. ${ }^{59}$

In Ben Nevis the court rejected judicial attempts to place glosses on the section, saying that these had too often been seized upon as the equivalent to statutory language. Ascertaining whether an arrangement amounted to tax avoidance, the court said, had to be grounded in the statutory language of the avoidance provision and any provision that the taxpayers were seeking

\footnotetext{
${ }^{54}$ Income Tax Act 2007, s GA 1.

${ }_{55}^{55}$ Rebecca Prebble and John Prebble, above n 48, at 29.

${ }^{56}$ Michael Littlewood "Tax Avoidance, the Rule of Law and the New Zealand Supreme Court" [2011] NZ L Rev 35 at 37.

${ }^{57}$ See for example Commissioner of Inland Revenue v Gerard [1974] 2 NZLR 279 (CA) at 280.

${ }_{58}^{58}$ Elmiger v CIR [1966] NZLR $638(\mathrm{CA})$ at 688.

${ }^{59}$ GT Pagone "Aspects of Tax Avoidance: Trans-Tasman Observations" (paper presented to the International Fiscal Association Conference, Wellington, March 2011) at 14.
} 
to rely on to gain a tax advantage. ${ }^{60}$ The majority of the court therefore laid down what has become known as the parliamentary contemplation test to determine whether an arrangement amounts to tax avoidance. This test will be discussed in greater detail in the following section. The test is based on a purposive interpretation of the avoidance provision and the provision relied on by the taxpayer. Now that the court refuses to use judicial glosses to limit the scope of the section, the rejection of a strict interpretation of the section alone cannot be seen as creating uncertainty in the application of the GAAR, or leading to a law containing only penumbra. Accepting the argument that the lack of a literal approach to the avoidance section in itself results in a law containing only penumbra would be endorsing the view rejected earlier that purposive interpretation inevitably leads to less certainty than literal interpretation. Furthermore, the Supreme Court itself rejected the view that all tax avoidance decisions would come within the penumbra or margin of the law. The court said that: ${ }^{61}$

As in many areas of the law, there are bound to be difficult cases at the margins. But in most cases we consider it will be possible, without undue difficulty, to decide on which side of the line a particular arrangement falls.

There are two further reasons why the GAAR appears to have a larger penumbra than most laws. The first is the reason behind the GAAR itself. GAARs are enacted to cover tax avoidance arrangements which the legislature has not considered. ${ }^{62}$ For example, GAARs will apply to prevent the use of a provision to gain a tax advantage in a manner that the legislature could not have foreseen. The presence of a GAAR in legislation is recognition that it is not possible for the legislature to predict all of the different structures that may be used to avoid tax. ${ }^{63}$ The second reason that the GAAR seems to contain a larger penumbra than most laws is a result of the nature of tax planning and tax avoidance. In other areas of the law, people tend to "stick to the well-trodden path". ${ }^{64}$ In tax avoidance cases, however, taxpayers invent new schemes and deliberately place themselves close to the boundary of the law to test how much they can get away with. ${ }^{65}$ This results

\footnotetext{
${ }^{60}$ Ben Nevis, above n 4, at [103].

${ }^{61}$ Ben Nevis, above n 4, at [112].

${ }^{62}$ Rebecca Prebble and John Prebble, above n 48, at 29.

${ }^{63}$ Rebecca Prebble and John Prebble, above n 48, at 30.

${ }^{64}$ Eberson, above $\mathrm{n} 84$, at 269.

${ }^{65}$ Eberson, above n 84, at 269. See also John Braithwaite "Rules and Principles: A Theory of Legal Certainty" (2002) 27 Australian Journal of Legal Philosophy 47 at 54.
} 
in more of the cases that come before the courts being within the penumbra of the law.

If it is accepted that the GAAR is not only penumbra, it is necessary to establish in which circumstances a case concerning tax avoidance will amount to a hard case. In order to come to a conclusion on this point, the parliamentary contemplation test laid out in Ben Nevis must be examined in greater detail.

\section{$B$ The Parliamentary Contemplation Test}

The approach outlined by the majority of the Supreme Court in Ben Nevis ascertained the meaning of s BG 1 by looking at the relationship between the avoidance provision and other sections of the Act that give some sort of tax advantage. The court said that if a taxpayer has used a section in a way that falls within the ordinary meaning of that section and gained a tax advantage, this will be a permissible tax advantage. ${ }^{66}$ However, where a taxpayer has used a specific provision in a way which falls outside of the intended scope of the provision in the overall scheme of the Act and gained a tax advantage, then this use will amount to an impermissible tax advantage and the arrangement will be void under s BG $1 .{ }^{67}$ As the court said: ${ }^{68}$

If, when viewed in that light, it is apparent that the taxpayer has used the specific provision, and thereby altered the incidence of income tax, in a way which cannot have been within the contemplation and purpose of Parliament when it enacted the provision, the arrangement will be a tax avoidance arrangement.

25 The court then set out a number of factors that were important to look at when considering a tax avoidance arrangement. These were the manner in which the arrangement was carried out, the role of all relevant parties and their relationship with the taxpayer, the economic and commercial effect of the transactions, the duration of the transaction and its financial

30 consequences for the taxpayer. A classic indication of a use of a provision that is outside of Parliament's contemplation, the court said, was where the transaction was structured so that the taxpayer gained the benefit of the specific provision in an artificial or contrived way. ${ }^{69}$ More recently, the parliamentary contemplation test was followed by the Court of Appeal in its 35 decision in Alesco New Zealand Limited $v$ Commissioner of Inland

${ }^{66}$ Ben Nevis, above n 4, at [106].

${ }_{68}^{67}$ At [106].

${ }^{68}$ At [107].

${ }^{69}$ At [108]. 
Revenue. $^{70}$ After laying out the test and the above factors, the court noted that artifice and contrivance could be hallmarks of tax avoidance. ${ }^{71}$

At first glance, the court's approach in Ben Nevis seems to be rather like the court laying down its own test for tax avoidance, and setting out a number of factors that will point to an avoidance arrangement. However, the majority emphasised that it was not setting out its own rule or providing a judicial gloss on the operation of the section. As already stated, the majority emphasised that where the line should be drawn between tax avoidance and tax mitigation should be firmly grounded in the statutory language of the provisions themselves. ${ }^{72}$ The definition of avoidance is an arrangement that directly or indirectly alters the incidence of income tax. However, many of the sections of the Act encourage a taxpayer to undertake courses of action which alter tax. Therefore, it is only when tax has been altered by using a section in a way not contemplated by Parliament that there has been tax avoidance.

\section{$C$ The Effect of the Parliamentary Contemplation Test upon when s BG 1}

\section{Will Be a Hard Case}

The previous section of this paper left open the question of when a given case will be a hard case within the penumbra of the GAAR. According to

20 Eugene Trombitas, hard cases will arise when the intention of Parliament is inadequately or imperfectly expressed. ${ }^{73}$ This paper accepts that the parliamentary contemplation test is, as the majority said, the result of an exercise in statutory interpretation based on reconciling the GAAR and the specific statutory provision of the Income Tax Act. This acceptance means

25 that Trombitas' theory must be correct. Hard cases will arise when it is not clear whether the arrangement in question is, or would have been, within Parliament's contemplation when it enacted a specific provision. This will occur when it is hard to ascertain what Parliament's intention was when it enacted a certain provision. Therefore, the question is whether in these cases,

30 where the judge is unable to ascertain whether the specific section would have been meant to apply to a particular arrangement, judges appear to look to principles to see whether they should apply the GAAR or not.

The parliamentary contemplation test limits uncertainty in the GAAR's application to the extent that the Supreme Court has resolved the test that the

${ }^{70}$ Alesco New Zealand Limited v Commissioner of Inland Revenue [2013] NZCA 40, [2013] 2 NZLR 175.

${ }^{71}$ At [25].

${ }^{72}$ Ben Nevis, above n 4, at [104].

73 Eugene Trombitas "Comment: Trinity Exposed: Does the Emperor Really Have No Clothes or is He Wearing an Unusual Silver Rugby Jersey? The Latest News from the GAAR Front" (2007) 13 NZJTLP 583 at 593. 
courts will apply to determine whether there has been tax avoidance. However, because pre-Ben Nevis approaches to the GAAR were not directly based on statutory interpretation but allowed for judicial glosses and judgemade rules, ${ }^{74}$ the application of the GAAR was a hard case in all

5 circumstances. This is because it was never clear where, or based upon what, judges would choose to draw the line between tax avoidance and tax mitigation. The GAAR's application was not governed by the words of the provision, but by varying judicial glosses placed on the section. Ben Nevis itself was arguably a hard case, not because of the facts of the case, but because of these same reasons; the court was faced with differing interpretations and conflicting precedent on the GAAR.

The result of the foregoing discussion is the conclusion that, due to judicial approach to the section prior to Ben Nevis and the nature of tax planning, the application of the GAAR did and still does often leave room for 15 judges to apply principles in reaching their decisions. The next section will therefore explore what the principles that judges may rely on in hard cases are.

\section{What Are the Possible Principles in Tax Law?}

This section of the paper draws on secondary literature to discover principles

20 that tax scholars have identified as underlying tax law. Tax avoidance judgments will then be analysed to establish whether the influence of the two principles identified in the secondary literature can be felt in judgements.

First, it is notable that tax law is often described as an area of law which is full of contradictions and competing interests and policies. This is

25 important to remember when searching for principles because it suggests that this area of law is more likely to have conflicting underlying principles. For example, in the Court of Appeal decision in the case of Challenge Corporation $v$ Commissioner of Inland Revenue, Richardson J noted in his judgment that it was "obviously fallacious to assume that revenue legislation

30 has a totally coherent scheme or that it follows a completely consistent pattern." 75 One reason may be the need to make tax law workable, and so rather than the overarching consideration being to create law based on interrelated, logical principle, the driving factor is practicality. ${ }^{76}$ Similarly,

\footnotetext{
${ }^{74}$ See for example the criticism of the judicial application of the GAAR in Thomas J's dissenting judgment in Commissioner of Inland Revenue v BNZ Investments Ltd [2002] 1 NZLR 450 at [63].

${ }^{75}$ Challenge Corporation v Commissioner of Inland Revenue [1986] 2 NZLR 513 (PC) at 549.

${ }^{76}$ John Prebble "Why is Tax Law Incomprehensible?" [1994] British Tax Review 380 at 390-393.
} 
Mark Burton argued that when tax legislation is brought to the court it almost invariably embodies a compromise. He said that this compromise leaves the way open for alternative interpretations of that compromise. ${ }^{77}$ The competing values embodied in tax statues are often identified as the values 5 of individualism and communalism. ${ }^{78}$ These competing values have been articulated in two distinct principles that emerge in secondary literature about tax law. The first is the principle that tax should apply uniformly to all cases that are economically similar. ${ }^{79}$ The second principle is that the taxpayer is entitled to structure his affairs to pay no more tax than the law requires. ${ }^{80}$

\section{A Tax Should Apply Uniformly to All Cases That are Economically Similar}

The first principle identified in legal commentary on tax law reflects a communal view of the taxation system. It is expressed by John Miller as the principle that tax should apply uniformly to all cases that are economically similar. ${ }^{81}$ This principle is also often expressed as the ability-to-pay principle, and it is this principle that provides a justification for a system of progressive taxation based on income rather than any other criteria. ${ }^{82}$ Miller's articulation of the principles is adopted in this paper because his articulation emphasises the comparative nature of the principle. The principle embodies the belief that the tax system should strive for horizontal and vertical equity; that is, that taxpayers who are similarly situated should be treated in the same manner, and that there should be fairness in the taxation of different income classes. ${ }^{83}$ According to this principle, a fair share of tax is the amount of tax that is equal to the amount that a similarly placed taxpayer is paying, regardless of whether this amount could be lowered through tax planning or schemes. Inherent in the principle is the acceptance that it is important that people believe that the tax system treats them fairly. Because the tax system rests on voluntary compliance, it is important that taxpayers perceive that they are being treated equally with

\footnotetext{
77 Mark Burton "The Rhetoric of Tax Interpretation- Where Talking the Talk is Not Walking the Walk" (2005) 1(3) Journal of the Australasian Tax Teachers Association 1 at 19.

${ }^{78}$ Balkin, above n 19 , at 413 .

${ }^{79}$ John A Miller "Indeterminacy, Complexity, and Fairness: Justifying Rule Simplification in the Law of Taxation" (1993) 68 Washington Law Review 1 at 13-14; Joseph M Dodge "Theories of Tax Justice: Rumination on the Benefit, Partnership, and Ability-to-Pay Principles" (2005) 58 New York University Tax Law Review 399.

${ }^{80}$ Miller, above $\mathrm{n} 79$, at 14 .

${ }^{81}$ Miller, above n 79, at 13-14. Miller uses the word "case" in a wider economic rather than as referring to a legal case.

${ }^{82}$ See for example Dodge, above n 79, at 449; Anthony C Infanti "Tax Equity" (2008) 55 Buffalo Law Review 1191 at 1226

${ }^{83}$ Michael A Livingston "Radical Scholars, Conservative Field: Putting Critical Tax Studies into Perspective” (1998) 76 North Carolina Law Review 1791 at 1793-1796.
} 
other taxpayers, otherwise it is less likely that they will comply with their obligations. ${ }^{84}$ Sir Ivor Richardson also noted that this principle of tax views tax avoidance arrangements as sterile and unproductive and having social consequences that are contrary to the general public interest. ${ }^{85}$

Tony Honoré argued that in complex modern societies, law is necessary to give effect to vague moral norms. ${ }^{86}$ Taxation gives shape to the abstract moral duty to contribute to one's society. ${ }^{87}$ According to this first principle, therefore, this duty is defined by Parliament in the amount of taxes that should be paid, and this is an amount which is consistent with the amount paid by others in similar circumstances.

The inevitable result of this principle is the application of a substance over form approach to tax avoidance. ${ }^{88}$ This is because the only way that tax can apply equally to all cases that are economically similar is if judges look past the legal form of transactions to their economic substance. The doctrine of substance over form requires the court to look at whether the economic reality of a transaction matches the legal form that it is expressed in, so that the transaction can be taxed according to the economic reality. This approach to taxation was also endorsed by Sir Edmund Thomas. He said that because income is derived from the substance of a transaction and not its

20 form, in order to collect tax on net income, ${ }^{89}$ the courts needed to look at the substance of the transaction. ${ }^{90}$ Thomas described this as the basic principle which had influenced his approach to all taxation cases. ${ }^{91}$

\section{B Taxpayers Are Entitled to Structure Their Affairs So As to Pay No More}

\section{Tax Than the Law Requires}

25 The second principle identified in the secondary literature is that taxpayers may structure their affairs so as to pay no more tax than the law requires. As Sir Ivor Richardson put it, according to this view of taxation, taxes are enforced extractions and everyone is entitled to arrange their affairs to make the tax that is payable as low as possible. ${ }^{92}$ This principle is to some extent contradictory with the first principle because, rather than emphasising

\footnotetext{
${ }^{84}$ Harry Ebersohn "Tax Avoidance and the Rule of Law" [2012] NZ L Rev 243 at 250.

${ }^{85}$ Richardson "Reducing Tax Avoidance by Changing Structures", above n 40, at 270-271.

${ }^{86}$ Tony Honoré "The Dependence of Morality on Law (1993) 13 Oxford Journal of Legal Studies 1 at 49.

${ }^{87}$ Zoe Prebble and John Prebble, above n 30, at 763.

${ }^{88}$ Miller, above 79, at 14.

${ }^{89}$ This is one of the purposes of the Act: Income Tax Act 2007, s AA 1(a).

${ }^{90}$ See Thomas' dissenting judgment in Peter $v$ Davison [1999] 2 NZLR 164 (CA) at 201 as discussed in EW Thomas "The Evolution from Form to Substance in Tax Law", above $n$ 42 , at $18-19$.

${ }^{91}$ Thomas "The Evolution from Form to Substance in Tax Law", above n 42, at 19.

${ }^{92}$ Richardson "Reducing Tax Avoidance by Changing Structures", above n 40, at 269.
} 
communal obligations to contribute to society, it emphasises individualist notions such as the right to property, the right to be free from overreaching government and freedom of contract. ${ }^{93}$ Nevertheless the two principles will not always conflict. Taken together, the principles hold that every taxpayer should be taxed in the same way as other taxpayers who are similarly situated, and that they may all use the available opportunities to minimise the amount of tax that they must pay. The principles will conflict when the second principle is taken to the extreme and tax is minimised in such a way that the transaction results in significantly lower tax liability than similar transactions.

The second principle proceeds from a belief that although the government has the power to collect tax, it has no intrinsic right to a set amount of property. ${ }^{94}$ Rather, if the government wishes to collect tax, it must impose tax in clear and unambiguous terms. ${ }^{95}$ If it does not do so, the taxpayer is entitled to use any ambiguity in the legislation to lower the amount of tax that he or she must pay. Miller argues that this principle is often the principle that is appealed to by tax planners. Because tax planners wish to minimise their tax obligations, and cannot do so unless they know where the lower limit of what they must legally pay is, this principle is often embodied in calls for certainty in tax law and the application of tax statutes. ${ }^{96}$ Taxation is fair, according to this principle, when the application of the law is predictable and certain. $^{97}$

Appeals for certainty in the law are often used to justify a black letter or literal interpretation of the law. However, a literal interpretation of a statute does not inevitably lead to greater certainty than purposive interpretation. ${ }^{98}$ For example, a literal interpretation may lead to less certainty when it results in absurdity. ${ }^{99}$ The underlying principle, which is that taxpayers are entitled to structure their affairs so as to pay only the amount of tax which the law requires, can still be determined through purposive interpretation. In other words, the amount of taxation that the law requires may be the amount that the statute, when interpreted purposively, imposes.

It is important to separate the underlying principle from the use of black letter interpretation of tax statutes so that criticism of the use of this

\footnotetext{
93 Jinyan Li "Comparative Tax Law and Culture: Tax Transplants and Local Culture: A Comparative Study of the Chines and Canadian Gaar" (2010) 11 Theoretical Inquiries in Law 655 at 679.

${ }_{95}^{94}$ Miller, above n 79, at 14 .

${ }^{95}$ Ebersohn, above n 84, at 249.

${ }^{96}$ Miller, above n 79, at 15 .

${ }^{97}$ Miller, above n 79, at 15 .

${ }^{98}$ Miller, above n 79, at 45-46.

${ }^{99}$ See Ofer Raban “The Fallacy of Legal Certainty” (2010) 19/175 Boston University Public Interest Law Journal 1 at 5.
} 
interpretation is not confused with criticism of the principle itself. However, the underlying principle has also been subject to criticism. For example, Zoe Prebble and John Prebble explain the critique of the principle that is based on John Locke's theory of property. According to this line of argument, the principle rests upon the false, or at least unsubstantiated, assumption, noted above, that a taxpayer has a moral entitlement to his or her pre-tax income. ${ }^{100}$ This assumption is based upon the belief in a moral right to one's property, which is seen as encompassing pre-tax income. However, this belief is arguably incorrect if property rights are seen as a creation of a legal system, because of the link between property rights, government and taxation. A legal system cannot exist without government, and government depends upon taxation, therefore, property rights depend on taxation. ${ }^{101}$

This essay will return to the appropriateness of applying this principle in the context of the anti-avoidance rule. Before rejecting this principle outright, however, this essay will assess whether it is possible to discern the influence of this principle, or of the previous principle, in any of the courts' decisions concerning tax avoidance.

\section{Are the Antecedent Principles Dworkinian Principles?}

In order for any presence of the two identified principles to support

20 Dworkin's interpretation of judicial reasoning, it must first be shown that the identified principles could be considered principles according to Dworkin's theory. The two principles represent different ideas of the circumstances which make the tax system fair and just. According to the first principle, the fundamental basis on which the fairness of the taxation system is judged is whether there is equality between similarly placed taxpayers. According to the second principle, it is fair that people are able to take advantage of any incentives that the tax system offers, even if this would lead to them being treated more favourably than others in similar circumstances. The focus of the principles on what is fair provides preliminary support for the hypothesis that they could be Dworkinian principles. Further support can be gleaned by comparing them to an example of principles given by Dworkin. In Law's Empire, Dworkin discusses the possible principles underlying the awarding of damages in negligence. He uses the search for underlying principles as an example of how a judge could be guided when assessing whether to award damages in a case of emotional injury as opposed to physical injury. Traditionally, damages in negligence were only available in cases of

\footnotetext{
${ }^{100}$ Zoe Prebble and John Prebble, above n 30, at 719.

${ }^{101}$ Zoe Prebble and John Prebble, above n 30, at 720-721, citing Liam Murphy and Thomas Nagel The Myth of Ownership: Taxes and Justice (Oxford University Press, New York, 2002) at 74 .
} 
physical injury. Dworkin lays out six possible principles and then discusses which of these would be the best interpretation of the principle underlying negligence law. ${ }^{102} \mathrm{He}$ concludes that the most appropriate articulation of the principle underlying negligence law is either that (1) people have a moral right to compensation for emotional or physical injury that is the consequence of careless conduct, but only if that injury was reasonably foreseeable or (2) that people have a moral right to compensation for reasonably foreseeable injury but not in circumstances when recognising such a right would impose a disproportionate burden on the person who

10 caused it. ${ }^{103}$ Either of these principles could provide the underlying basis upon which any award of damages should be made. This shows that Dworkin conceives of principles as being of a breadth capable of guiding the interpretation and application of an entire area of the law. The principles described above are notions of justice and fairness of a similar breadth to

15 Dworkin's examples of principles. Which of these principles is favoured by the judge will guide the judge's interpretative approach to every application of tax legislation and justify the decision reached. It is therefore appropriate to use these principles when searching for the influence of principles in the judicial application of the avoidance provision.

$20 V$ A Search for the Presence of Principles in Tax Avoidance Decisions

There are a number of arguments that repeatedly surface in tax avoidance cases. These arguments are used to advocate a particular approach to the GAAR. This section will consider the extent to which any of these arguments

25 are influenced by, or can be seen to embody, either of the previously identified principles. If the arguments did embody the principles, this would provide support for the proposition that the principles are used to ascertain the correct scope of the GAAR. The relevant arguments are: the Duke of Westminster principle, the GAAR should not deprive the taxpayer of the

30 opportunity to choose tax beneficial options, the courts should respect commercial certainty and the scope of the GAAR must be ascertained by looking at the relationship between it and the other sections of the Act. This section will conclude that although the first three arguments initially seem to support the second principle, the Supreme Court's approach in Ben Nevis to

35 each of these arguments means that they no longer provide any real support for the principle that taxpayers are entitled to structure their affairs to keep

${ }^{102}$ Dworkin, Law's Empire, above n 6, at 242.

${ }^{103}$ At 248-250. 
their taxes as low as possible. The final argument amounts to no more than an argument of statutory interpretation. This again leaves the parliamentary contemplation test. The next section of the essay will discuss the parliamentary contemplation test, and evaluate whether this test demonstrates the presence of principles in tax avoidance decisions.

\section{A The Duke of Westminster Principle}

In the famous case of Inland Revenue Commissioners $v$ Duke of Westminster, Lord Tomlin provided explicit judicial recognition of the second identified principle. His Lordship said that "every man is entitled, if he can, to order his affairs so that the tax attaching under the appropriate Act is less than it otherwise would be."104 The Duke of Westminster principle has been extremely influential in United Kingdom tax avoidance jurisprudence; however, its practical effect has arguably been reduced by the doctrine of fiscal nullity. ${ }^{105}$ This doctrine, laid down in the case of WT Ramsay $v$ Inland

15 Revenue Commissioners, allows a purposive approach to be taken to the interpretation of tax statues rather than the strict interpretation in the Duke of Westminster. ${ }^{106}$ The impact of the Duke of Westminster principle can be seen in New Zealand case law in the second prominent argument raised in tax avoidance cases. Therefore, this essay will discuss that argument in more detail.

\section{$B$ The GAAR Should Not Deprive Taxpayers of Tax Beneficial Choices}

The claim that taxpayers should have the ability to choose tax beneficial options is one of the most persistent arguments in tax avoidance jurisprudence. It has now become known as the choice principle. The argument was originally accepted by the Australian High Court in the case of WP Keighery v Federal Commissioner of Taxation. In this case the court said that the Australian GAAR was intended: ${ }^{107}$

only to protect the general provisions of the Act from frustration, and not to deny to taxpayers any right of

\footnotetext{
${ }^{104}$ Inland Revenue Commissioners $v$ Duke of Westminster [1936] AC 1 (HL). The influence of this principle has been felt across the Commonwealth. For example, in Canada, the Declaration of Taxpayers' Rights issued by the Canada Customs and Revenue Agency says that taxpayers are entitled to arrange their affairs to pay the least amount of tax the law allows. Discussing this case in "Reflections on the Relationship between Statutory Interpretation and Tax Avoidance" (2001) 49 Canadian Tax Journal 1 Brian Arnold noted that the case represented the fundamental principle on which Canadian tax-avoidance law was based.

${ }^{105}$ Sheila E Foster "Westminster Consigned to the Furnace”(1984) 8 Trent Law Journal 65 at 68-69.

${ }^{106}$ WT Ramsay Ltd v Inland Revenue Commissioners [1982] STC 174.

${ }^{107}$ WP Keighery Pty Ltd $v$ Federal Commissioner of Taxation (1957) 100 CLR 66 (HCA) at 92.
} 
choice between alternatives which the Act itself lays open to them.

The court said that it was therefore important: ${ }^{108}$

to consider whether the result of treating the section as applying in a case such as the present would be to render ineffectual an attempt to defeat etc a liability imposed by the Act or to render ineffectual an attempt to give a company an advantage which the Act intended that it might be given.

10 This reasoning was later adopted by Richardson $\mathrm{J}$ in Challenge. $\mathrm{He}$ considered that the case provided powerful support for the proposition that adopting a course of action that the Income Tax Act specifically contemplated as effecting a tax change does not amount to tax avoidance. ${ }^{109}$ The decision of the Privy Council in Miller $v$ Commissioner of Inland

15 Revenue also reflected this idea. If the legislation, upon its true construction was intended to give the taxpayer the choice of avoiding tax in this way, their Lordships said that such action would not engage the GAAR. ${ }^{110}$

The idea that taxpayers may choose a more tax beneficial option very closely resembles the principle that taxpayers are entitled to structure their

20 affairs so as to pay no more tax than the law requires. However, the principle should not be seen as giving taxpayers free rein to engage in aggressive tax planning or tax avoidance. This is perhaps most clearly seen in the way that the New Zealand Supreme Court addressed this argument: ${ }^{111}$

Taxpayers have the freedom to structure transactions to their best tax advantage. They may utilise available tax incentives in whatever way the applicable legislative text, read in the light of its context and purpose, permits. They cannot, however, do so in a way that is proscribed by the general anti-avoidance provision.

30 As noted, the principle that taxpayers are entitled to structure their affairs so as to pay no more tax than the law requires has often been used to justify a black letter approach to revenue legislation that sees the GAAR as inconsistent with the idea of imposing tax in a principled and certain matter. However, this principle itself is not necessarily inconsistent with the GAAR if 35 it is accepted that the GAAR is a part of determining the amount of taxation

${ }^{108}$ Keighery, above n 107, at 92-93.

${ }^{109}$ Challenge (CA), above $\mathrm{n} 75$, at 552.

${ }^{110}$ Miller, above n 24, at [9].

${ }^{111}$ Ben Nevis, above n 4, at [111]. 
that the law requires. In other words, the freedom to structure affairs only extends to paying as little tax as is consistent with the operation of the GAAR.

While this means that this principle is still consistent with judicial interpretation of the GAAR, in reality the interpretation of the choice

5 principle by the majority of the court in Ben Nevis leaves the underlying principle with very little guiding force. The purpose of Dworkin's principles is to point judges to the interpretation of the law that is the best in terms of justice and fairness. However, applying the principle that you are entitled to pay as little tax as the law requires, only in so far as this is consistent with how much the GAAR says that you must pay, does not provide any tool for pointing to whether the GAAR should apply in a given situation or not. As interpreted in Ben Nevis, this principle is of no use in determining the appropriate scope of the GAAR.

\section{The Need for Commercial Certainty}

15 The argument that the GAAR must be interpreted in a way that gives a reasonable amount of certainty to taxpayers is another argument that has been used to support a narrower interpretation of the GAAR. As explained above, the plea for certainty can be seen as an adoption of the principle that taxpayers are entitled to structure their affairs to pay no more tax than the

20 law requires. This is because, it is argued, the only way that taxpayers can make their obligations as low as possible is if it is clear what the lowest amount of tax they can legally pay is. Judicial acceptance of the plea for commercial certainty could therefore be seen as an embodiment of the second principle and an indication that judges have been influenced by the principle. However, courts have often been careful in accepting arguments based on the importance of certainty. For example, in BNZ Investments the majority said that certainty and predictability were important but not absolute values. ${ }^{112}$ In his dissenting judgment in that case Thomas $\mathrm{J}$ noted that there was an unrealistic expectation of the certainty that it is possible to obtain with a GAAR. While it is desirable to achieve as much certainty as possible, general anti-avoidance provisions must necessarily be uncertain if they are to cover the multiplicity of schemes intended to avoid tax. ${ }^{113}$ Further, the courts have considered that the claim that uncertainty is created for the general taxpayer by the operation of the GAAR requires serious but 35 sceptical consideration. ${ }^{114}$ Although would-be tax-avoiders claim that a narrower interpretation of the provision would protect the interest in certainty for the general body of taxpayers who do not engage in tax

${ }_{112}$ BNZ Investments, above $\mathrm{n} 74$, at [40].

${ }_{113}$ BNZ Investments, above $\mathrm{n} 74$, at [91].

${ }^{114}$ Challenge (PC), above $\mathrm{n} 75$, at 560. 
avoidance, Lord Templeman considered that this argument lost force once it was accepted that there are discernable distinctions between a transaction which mitigates tax and one that avoids tax. ${ }^{115}$ In Ben Nevis the majority rejected the taxpayer's argument to interpret the GAAR in a way which gave the taxpayer reasonable certainty in tax planning. The majority said that Parliament had left the provision deliberately general. It was not for the courts to provide greater certainty than Parliament had chosen to provide. ${ }^{116}$

The enactment of a GAAR is to some extent contradictory with the value certainty because of the fact that it is designed to cover transactions that

10 Parliament has not considered. Further, the Supreme Court refused to lay down its own test for tax avoidance that gave greater certainty by providing, for example, a specific closed list of what behaviour would amount to tax avoidance. This means that to the extent that pleas for commercial certainty are invoked to limit the scope of the GAAR, following Ben Nevis, these pleas have been rejected. The result is that the hypothesis that judges have been influenced by the underlying principle that taxpayers are entitled to structure their affairs to lower the amount of tax that they must pay, because of the fact that this is what underlies pleas for commercial certainty, can no longer be substantiated.

20 D The Scope of the GAAR Must Be Ascertained through Looking at the Relationship Between the GAAR and the Rest of the Act.

The final approach that the court has taken when it is deciding whether the GAAR should apply in a given situation is to look at the relationship between the GAAR and other sections of the Act. This was the basis of what has

25 become known as the scheme and purpose approach that was laid down by Richardson J in Challenge. The majority of the Supreme Court in Ben Nevis also reached its decision based on the GAAR's relationship to other sections.

In Challenge Richardson $\mathrm{J}$ said that the avoidance provision lived in an uneasy compromise with other provisions of the legislation. Reconciling the

30 provisions must depend upon an assessment of the respective roles of the particular provision relied upon to gain a tax advantage and the avoidance provision as well as the relationship between them. He considered that this process of reconciling the provisions was a matter of statutory construction. Section 5 of the Acts Interpretation Act $1924^{117}$ mandated that the meaning

35 of a provision was ascertained by looking at the scheme and the relevant objectives of the legislation. ${ }^{118}$ Richardson $\mathrm{J}$ described the scheme and

${ }^{115}$ Challenge (PC), above $\mathrm{n} 75$, at 560 .

${ }^{116}$ Ben Nevis, above n 4, at [112].

${ }^{117}$ Now replaced by the Interpretation Act 1999.

${ }^{118}$ Challenge (CA), above $\mathrm{n} 75$, at 549. 
purpose of the legislation as the twin pillars of statutory construction. ${ }^{119}$ Richardson J eventually reconciled the avoidance provision and the relevant particular provision by reading down the scope of the avoidance provision. On appeal, the Privy Council disagreed with Richardson J's assessment of the scope of the avoidance provision, but nevertheless endorsed his view that the section would be a dead letter if it were subordinate to all of the specific provisions of the Act. This would be the case, Lord Templeman said, if mechanical or meticulous compliance with another section of the Act were sufficient to prevent the application of the avoidance provision. ${ }^{120}$

After discussing the differing approaches to the avoidance provision in Challenge, the majority in Ben Nevis briefly surveyed the subsequent case law, concluding that this case law had proceeded, albeit sometimes implicitly, on the basis of the scheme and purpose approach. ${ }^{121}$ However, the majority noted that in Commissioner of Inland Revenue $v$ Auckland Harbour Board, the Privy Council seemed to have placed significantly less emphasis on the GAAR by indicating that it might only be a long stop, or backup provision, for the Commissioner. As a result of the uncertainty arising from the approach in Auckland Harbour Board the Supreme Court considered it desirable for it to settle the appropriate approach to the relationship between

20 this provision and the rest of the Act. ${ }^{122}$ The majority considered that Parliament's overall purpose was best served by construing specific tax provisions and the general-anti avoidance provision so as to give effect to each. Neither of these provisions should be thought of as overriding, rather they should work together. ${ }^{123}$ Like Richardson J, the majority also thought that the avoidance and specific provisions had conflicting purposes and policies. The general anti-avoidance provision is meant to be the principal vehicle for tax avoidance to be addressed, while each specific provision has its own specific meaning which had to be distinguished from that of the avoidance provision. ${ }^{124}$ Bearing these factors in mind, the court laid down the parliamentary contemplation test already discussed.

These two cases demonstrate that ascertaining the relationship between different sections of the Income Tax Act was an important part of the process of working out the appropriate scope of s BG 1. However, there is nothing in this approach that embodies either of the two identified

${ }^{119}$ Challenge (CA), above $\mathrm{n} 75$, at 594.

${ }^{120}$ Challenge (PC), above $\mathrm{n} 75$, at 559.

${ }^{121}$ Ben Nevis, above n 4, at [95] - [96].

122 At [100].

123 At [103].

${ }^{124}$ At [103]. 
engaging in a process of statutory interpretation to ensure that it gave sufficient weight to both of the sections involved in the case.

This means that what is left after the Supreme Court's treatment of the above arguments is the parliamentary contemplation test. As noted above, like the argument that the scope of the GAAR must be ascertained through looking at its interpretation with the rest of the Act, this test was the result of a process of statutory interpretation. The finding that the scope of the GAAR must be ascertained by looking at whether the specific provision was used in a manner consistent with parliament's contemplation was not the result of the application of principles.

However, the parliamentary contemplation test is consistent with the first principle that tax should apply to cases that are economically similar. This is because the Parliamentary contemplation test focuses on artificial and contrived use of the specific provision. That is, it looks for factors such as artificiality and contrivance that would indicate a lack of economic substance in the transaction. These factors would indicate that the arrangement in reality is not economically similar to other transactions which were intended to come within the scope of the specific provision and so should not gain the same tax advantages as these transactions.

20 The parliamentary contemplation test is not consistent with the second principle that taxpayers may structure their affairs so as to pay no more tax than the law requires. If the ability to structure affairs only extends to structuring them in the manner consistent with Parliament's purpose, then really this principle has no force. The entitlement to arrange affairs to pay as little tax as possible is seriously curtailed by the parliamentary contemplation test. Therefore, the principle is not a legitimate way to guide interpretation of this test and must be rejected.

\section{The Role of Principles in Ascertaining Parliament's Contemplation}

30 The foregoing discussion of recurring arguments in tax avoidance cases has resulted in the conclusion that although cases decided prior to Ben Nevis endorse arguments that embrace the principle that taxpayers are entitled to structure their affairs so as to pay as little tax as possible, the interpretation of these arguments in Ben Nevis has resulted in this principle being of no

35 practical use in guiding judicial application of the GAAR. However, the parliamentary contemplation test is consistent with the first principle, that transactions should be taxed in the same way as others that are economically similar. Although the articulation of the test was not the result of the 
application of principles, this section of the paper will assess whether its application either by the court in Ben Nevis itself, or in subsequent cases, can be seen as having been guided by the first identified principle.

\section{A The Application of the Parliamentary Contemplation Test in Ben Nevis}

5 The most important features of the parliamentary contemplation test were laid out in the second section of this essay. To recap, the Supreme Court directed that the court was to look at the purpose of the specific provision and the intended scope of that provision in the overall scheme of the Act. If the transaction in the case used the specific provision in a manner outside of the intended scope, then it would amount to tax avoidance. Artificiality and contrivance were identified as classic indicators of use outside of Parliament's contemplation.

Ben Nevis involved a forestry venture. In 1997, the taxpayers were granted a licence to occupy a block of land owned by Trinity and maintain a forest of fir trees. The license was for 50 years because the fir trees were not due to be harvested until 2048. In return for the licence, the taxpayers agreed to pay Trinity a licence premium which was payable in 2048. The result of this was that the expense was not payable for 50 years. However, the taxpayers purported to pay this immediately by issuing a promissory note for the amount of the premium. Insurance was also taken out in the event that the harvesting of the fir trees did not cover the licence fee. The taxpayers then claimed deductions for the insurance premiums under s DL 1 of the Act and the licence premiums under s EG 1 of the Act. In 1997 they claimed deductions of $\$ 34,098$ per plantable hectare for the insurance premiums and a small proportion of the licence premium of $\$ 2,050,518$ per plantable hectare as a depreciation allowance. In 1998 the taxpayers claimed about $\$ 41,500$ per plantable hectare. In reality, the actual cost to the taxpayers was about $\$ 5,000$ per plantable hectare in 1997 and only $\$ 50$ per plantable hectare in $1998 .{ }^{125}$ The point of the venture was to enable the taxpayers to offset the claimed losses of $\$ 41,500$ per year against their other income. ${ }^{126}$

The majority of the Supreme Court held that the licence premium relied on by the taxpayer to claim the deduction was a licence premium because it was payable for a right to use land, as the statute required. However, the court considered that specific features of its use in the case, such as the method and timing of the arrangement meant that in reality the commitment to make the payment of the premium was illusory. The court held that in

${ }^{125}$ Ben Nevis, above n 4, at [14]- [31].

${ }^{126}$ See Michael Littlewood "Ben Nevis Forestry Ventures Ltd and Others v CIR; Glenharrow Lds v CIR - New Zealand's new Supreme Court and Tax Avoidance [2009] BTR 169 at 169. 
these circumstances claiming a deduction for the premium amounted to use of the deduction provision outside of its intended scope and transformed the arrangement into a tax avoidance arrangement. ${ }^{127}$ The taxpayers would get the immediate benefit of the deduction, but probably never incur the real 5 expenditure. ${ }^{128}$ In relation to the insurance aspect of the scheme the court found that the promissory note was an artificial payment implemented for tax purposes. The insurance company took on no real risk and this dimension of the scheme was artificial and contrived. This is because the economic effect of the payment was deferred by the promissory note for 50 years. Further, the insurer was not an arm's length insurer and had no ability to pay in the event that it was called upon to cover the loss. ${ }^{129}$ These factors led the court to conclude that neither claiming deductions for the insurance arrangements nor the use of the licence premiums in this case amounted to using s EG 1 or DL 1 of the Income Tax Act in the manner contemplated by 15 Parliament. ${ }^{130}$

The court's conclusion that the use of the deduction provisions was beyond Parliament's contemplation in enacting the provisions was in large part based on the artificial and contrived nature of the transactions. The taxpayers were trying to obtain the benefit of the deduction provisions for 20 expenses which in economic terms they had not actually sustained. The majority's judgment makes many references to the fact that the use of the provisions "cannot have been within the contemplation and purpose of Parliament" 131 and to the fact that it could not be within Parliament's purpose for a specific provision to be used in a way that allows the taxpayer 25 to gain the benefit of that section in an artificial or contrived way. ${ }^{132}$ However, the court never actually said why artificial uses of specific provisions must be beyond the contemplated use of those provisions. In other words, there is a gap in the reasoning between saying that it is necessary to look at parliament's intended scope of the deduction provision

30 in the overall scheme of the Act and the conclusion that it cannot have been parliament's intention for the deduction provision to be used in a manner that gains the benefit of that provision in an artificial or contrived way. As the IRD Interpretation Statement on s BG 1 notes, the majority's argument implicitly accepts that Parliament contemplates that provisions apply to transactions that correctly reflect their commercial reality and economic

${ }^{127}$ Ben Nevis at [107] and [130].

${ }^{128}$ At [127].

${ }^{129}$ At [147] and [148].

${ }^{130}$ At [148].

${ }^{131}$ At [107].

${ }^{132}$ At [108]. 
effects. ${ }^{133}$ Artificiality and contrivance are only indicators that the use of a specific provision was beyond what Parliament intended if Parliament intended that specific provisions are applied to transactions in a manner that reflects their economic reality rather than their legal form.

5 The majority's decision in Ben Nevis can therefore be seen as having been influenced by the underlying principle that tax should apply uniformly to all cases that are economically similar. This is because of the reliance that the court puts on the concepts of artificiality and contrivance without explaining why these factors will result in the transaction being outside of Parliament's contemplation. The implicit acceptance of the idea that Parliament contemplates that provisions apply to transactions that correctly reflect their commercial reality embraces the substance over form approach to questions of tax avoidance and the principle underlying this approach that transactions should be taxed in the same manner as other transactions that are economically similar.

\section{B Had Artificiality and Contrivance Previously Been Held to Be Signs of}

\section{Tax Avoidance?}

As has been pointed out above, there is a gap in reasoning between saying that it is important to work out what Parliament's intention was when enacting a specific provision and that factors such as artificiality and contrivance indicate that a scheme would not have been within Parliament's contemplation. One way that the gap could be filled, is if previous tax avoidance decisions had specifically found these factors to be features of tax avoidance arrangements.

References to the relevance of artificiality and contrivance as indicators of tax avoidance can be found in a number of decisions. ${ }^{134}$ For example, the Court of Appeal described the transaction in Dandelion Investments Ltd as an artifice involving pretence. The court considered that it was not a real 30 group transaction at all and amounted to tax avoidance. ${ }^{135}$ In Commissioner of Inland Revenue v BNZ Investments, the majority said that what should be struck at by the avoidance provision were artifices and arrangements which had tax induced features outside the range of acceptable practices. ${ }^{136}$

\footnotetext{
${ }^{133}$ Public Rulings Unit Interpretation Statement: Tax Avoidance and the Interpretation of sections BG 1 and GA 1 of the Income Tax Act 2007 (Inland Revenue Department, Wellington, 2013) at [309].

${ }^{134}$ Miller, above n 24, at [10]; Dandelion Investments Ltd v CIR [2003] 1 NZLR 600 (CA) at [85] and CIR v BNZ Investments Ltd [2002] 1 NZLR 450 (CA) at [40], [97] and [108].

${ }^{135}$ Dandelion Investments, above n 134, at [85].

${ }^{136}$ BNZ Investments, above n 134, at [40].
} 
Similarly, in Challenge Lord Templemann defined tax avoidance as when a taxpayer reduces his liability to tax without involving himself in the loss or expenditure which entitles him to that reduction. ${ }^{137}$ This definition embraces consideration of the substance of the transaction.

The above cases show that the Supreme Court's proposition that artificiality, contrivance and lack of economic reality are often hallmarks of tax avoidance was not new; rather it was the majority linking these features to use of a specific provision in a way that was beyond the contemplation of Parliament that involved reasoning that was not expressed clearly in the judgement itself. This leap in reasoning provides support for the proposition that the court was influenced by and endorsed the first discussed principle.

\section{$C$ The Application of the Parliamentary Contemplation Test Post-Ben Nevis}

Cases decided after Ben Nevis have applied the parliamentary contemplation test and are therefore also consistent with the principle that tax should apply uniformly in all cases that are economically similar. However, these cases made more obvious attempts to ascertain what Parliament's purpose in enacting the specific provision was than the court in Ben Nevis itself by analysing why transactions lacking economic substance were not intended to come within the scope of a specific provision. Drawing from these cases in the Inland Revenue Interpretative Statement on s BG 1, the Department said that purpose could be identified through considering the meaning of the text of the relevant provision, the context, including the statutory scheme, and any relevant legislative history. ${ }^{138}$ In Ben Nevis the Supreme Court said that the proper approach was to look at was the intention of Parliament "when it enacted the provision."139 Subsequently applying this test in $B N Z$ Investments Ltd $v$ Commissioner of Inland Revenue (No 2) Wild J agreed that this was a hypothetical task where the court essentially had to ask itself: had Parliament foreseen transactions of this type when enacting the specific provision deployed in the transactions, would it have viewed them within the scheme and purpose of those specific provisions? ${ }^{140}$

BNZ Investments (No 2) provides an example of the court engaging in a more thorough analysis of the purpose of the specific provision at issue. This case involved the conduit companies' regime. The judge looked at a discussion document when discussing the purposes of this policy but

${ }^{137}$ Challenge (PC), above $\mathrm{n} 75$, at 561.

${ }_{138}^{138}$ Public Rulings Unit, above n 133, at [226].

${ }_{139}^{139}$ At [107].

${ }^{140}$ BNZ Investments Limited v Commissioner of Inland Revenue No 224 NZTC 23,582 (HC) at [135]. 
Act. He concluded that the specific requirements for conduit companies in the Act would be pointless unless Parliament was contemplating that some of the conduit relieved income would be passed on to the foreign owner. ${ }^{141}$ As this had not happened on the facts of this case, the provision had not been used in a manner consistent with Parliament's purpose. This is therefore an example of a case where Parliament's purpose could be ascertained by a process of statutory interpretation.

Another case that demonstrates the court engaging in a more thorough analysis of Parliament's purpose is the Court of Appeal's decision in Alesco.

10 The court considered that the meaning, purpose and effect of the financial arrangements rules were at the heart of the case. ${ }^{142}$ The court said that the primary issue was whether, if Alesco New Zealand did not incur either a legal liability to pay interest or any economic cost on the loan from its Australian owner, its use of the financial arrangement rules and s G22 to 15 claim income tax deductions for expenditure incurred fell outside of Parliament's contemplation when enacting the rules. ${ }^{143}$ The court looked first at whether the purpose or intended scope of the financial arrangement rules relied on to claim the interest deductions. It set out these statutory provisions, including the purpose stated in the Act, and analysed the 20 language used in each provision. The court then looked to secondary literature that discussed the principal aims of the financial arrangements rules, and previous cases that had analysed the purpose of these rules. ${ }^{144}$ After discussing these materials the court considered that the financial arrangements rules were intended to give effect to real economic benefits and costs. The court therefore reached the conclusion that Parliament did not intend that a taxpayer would be entitled to use the financial arrangement rules as a basis for claiming deductions for interest for which the taxpayer was not liable or did not pay. ${ }^{145}$ It considered that this was consistent with the decision in Ben Nevis that the underlying premise for statutory

30 deductibility rules is that they apply only when real economic consequences are incurred. ${ }^{146}$

The decision in Alesco embraces the principle that transactions should be taxed in the same manner as other transactions that are economically similar. Following the approach in Ben Nevis, the court in Alesco took a substance over form approach and looked at the economic reality of the transactions.

${ }^{141}$ At [232]-[237].

${ }^{142}$ At [5]. These are found in Part EH of the Income Tax Act 2004.

${ }^{143}$ At [56].

${ }_{145}^{144}$ At [57]-[70].

${ }^{145}$ At [71]-[72].

${ }^{146}$ At [83]. 
However, before adopting this principle the Court of Appeal looked at why the principle was appropriate in the specific statutory context of the financial arrangements rules by analysing why Parliament's purpose was that real economic loss was sustained. The result of this is that the use of the principle was explicitly tied to a process of statutory interpretation, rather than implicitly accepted by the court. This means that although the first principle is embodied by the decision that there was tax avoidance, there is no evidence that the court's reasoning included reference to the principle. Because the purpose of the financial arrangements rules was clearly ascertainable, whether there was tax avoidance was decided by a process of statutory interpretation. The decision in Alesco demonstrates that the parliamentary contemplation approach may be applied through a process of statutory construction. That is, applying the parliamentary contemplation test does not always require relying on the underlying principle. Alesco therefore supports Hart's theory that it is only in hard cases that judges have the ability to reach their decision by recourse to principles. In this case the intended scope of the specific provisions was clearly expressed, so the case was not a hard case.

\section{Parliament's Contemplation: Should Principles Help?}

20 This paper has sought to assess whether judicial application of s BG 1 supports the hypotheses that judges use principles when reaching decisions. Based on extrajudicial writing on the subject, it has adopted the view that there is room for the application of principles, but only in some cases, when it is uncertain how the law should apply. Following the Supreme Court's approach to the avoidance provision in Ben Nevis, hard case will arise when parliament's intended scope of the specific provision used to gain a tax advantage is unclear. Where this is the case, it is possible for judges to assess whether s BG 1 should apply based on the underlying principle that tax should apply uniformly to all cases that are economically similar.

30 Despite the fact that the court in Ben Nevis may have been able to establish the intended scope of the specific provisions explicitly by looking at factors such as the legislative history of the provisions, the court did not do this. Instead, it based its analysis on factors that would indicate that the use could not have been within Parliament's purpose when it enacted the relevant 35 provisions. In the absence of this explicit analysis of what Parliament's intention for the scope of the specific provision was, the judgment can be seen as an example of the court being influenced by a Dworkinian principle in reaching its decision. The final section of the essay will assess whether it 
is appropriate for judges to decide hard cases concerning $\mathrm{S}$ BG 1 in this manner.

\section{A A Jurisprudential Approach}

Approaching this question with reference to the arguments of each of the

5 jurisprudential theories gives a different answer. Dworkin would argue that not only should judges decide hard cases by reference to principles, but that they are legally obliged to decide such cases in this way. ${ }^{147}$ Hart, on the other hand, does not make a judgment about whether it is desirable for judges to decide by reference to principles or not. Critical legal scholars would view the use of principles negatively as an example of the exercise of judicial discretion. ${ }^{148}$ Yet it is interesting that applying the GAAR according to this principle will arguably lead to a more expansive scope for the GAAR than saying that the section cannot apply because the scope of the specific provision is unclear. Because tax avoidance is often carried out by the wealthy or elite, ${ }^{149}$ the GAAR is a tool to stop the elite taking advantage of the legal structure for their own benefit. Applying the GAAR according to the first identified principle is therefore in line with critical legal scholars' aim.

The criticism of using principles in judicial reasoning often stems from the fact that courts do not explicitly say that this is what they are doing. If transparency in judicial decision-making is what is desired, then deciding according to principle should be acceptable as long as judges are clear that this is what is guiding their application of the GAAR.

\section{$B$ The Argument against Reliance on the First Principle}

One argument against the use of the principle stems from the use of the parliamentary contemplation test to determine the GAAR's scope in the first place. The wording of the GAAR only makes sense when read in conjunction with the rest of the Act. This means that relying on this underlying principle when the intended scope of the specific provision is unclear would in effect result in widening the GAAR's application and making this section the primary section of the Act. Because the GAAR itself must be understood through its interaction with other sections of the Act, then relying upon a principle, when this interaction is unclear, and in isolation from this wider context, is inappropriate. This is because the principle that tax should apply uniformly to all cases that are economically similar is broad and unconstrained. Unless the scope of the specific provision is also influenced

${ }^{147}$ Dworkin Law's Empire, above n 6, at 253.

${ }^{148}$ See for example Kress, above n 18.

${ }^{149}$ This is because wealthy taxpayers are the people with both the ability and the incentive to engage in tax avoidance. See for example Zoe Prebble and John Prebble, above n 28, at 726. 
by this principle, then using it to guide the application of the GAAR in hard cases will arguably lead to the GAAR having a wider application in these cases than in cases when the scope of the specific provision is clear. Further, it has been argued that where Parliament's intention is inadequately expressed, and the intended scope of the specific provision is not known, then it is not for the courts to use the GAAR to perfect the inadequate expression of Parliament's intention. Rather the courts must leave it up to Parliament to legislate if it wishes to fix the imperfections of the statute. ${ }^{150}$

\section{$C$ The Argument in Favour of Reliance on the First Principle}

10 On the other hand, strong support for the use of the principle to guide the application of the GAAR is provided by looking at the intended purpose of the avoidance provision itself. It is generally accepted that one tool for ascertaining Parliament's purpose in enacting a specific provision is to look at the legislative history of an Act. ${ }^{151}$ In this case, the GAAR was amended in 1975 to a form much like it is today. The speech given during parliamentary debate on the Bill by the Minister of Justice at the time, the Hon Dr AM Finlay MP, provides insight about the objective of the amendment. Dr Finlay noted two results of amending the GAAR to give it the force to be used as a tool to ensure that people paid tax as Parliament intended. The first was that the tax burden would be more equitably shared, resulting in a lightening of the burden for the ordinary taxpayer. ${ }^{152}$ The second was that tax legislation could be simplified. ${ }^{153}$

In this speech Dr Finlay also cited the dicta of several judgments as examples of differing approaches to tax avoidance. He noted the House of

25 Lords' decision in Latilla $v$ Inland Revenue Commisioner ${ }^{154}$ where their Lordships said that one result of tax avoidance arrangements was to increase: $^{155}$

pro tanto the load of tax on the shoulders of the great body of good citizens who do not desire, or do not know how, or... cannot afford to adopt [such] manoeuvres.

He also described the decision in the case of Elmiger and Another $v$ Commissioner of Inland Revenue as a landmark decision. ${ }^{156}$ At first instance, Woodhouse $\mathrm{J}$ had noted that tax avoidance arrangements were sterile and unproductive and had consequences contrary to the general

${ }^{150}$ Trombitas, above n 37, at 594.

${ }^{151}$ See for example Barak, above n 4, at 342- 350.

${ }^{152}$ (30 August 1974) 393 NZPD 4192.

153 At 4192.

${ }^{154}$ Latilla v Inland Revenue Commissioners [1943] AC 377 (HL).

155 At 4192.

${ }^{156}$ At 4192. 
public interest. ${ }^{157}$ This decision was affirmed by the Court of Appeal. ${ }^{158}$ Finally, he said that: ${ }^{159}$

If people choose to avoid paying tax by disposing of their income in a way that is totally different form the normal patterns of ordinary folks' spending... it should be treated as it really is- as a device to avoid bearing their share of the costs of running the community.

Dr Finlay's comments are directly in line with the principle that tax should apply uniformly to cases that are economically similar. His comments suggest that tax avoidance is something that can only be engaged in by wealthy taxpayers, and results in them paying an amount of tax that does not reflect their actual income and so distorts the equity of the tax system.

The legislative history of the anti-avoidance provision therefore demonstrates that Parliament's intention for the GAAR is consistent with and embodies the reasoning behind the first principle identified in this essay. The GAAR was enacted to ensure that the integrity of the tax system was maintained through transactions that were economically similar being treated the same way for tax purposes. This might suggest that when what is within Parliament's contemplation or intention in enacting the specific provision relied upon to gain a tax advantage is not easily ascertained, and the case therefore amounts to a hard case, it would be appropriate for the court to be guided by this principle in deciding whether or not to apply the GAAR.

25 Although the parliamentary contemplation test looks at Parliament's intention in enacting the specific provision, it does not look at Parliament's intention when enacting the GAAR. However, an examination of the legislative history of the avoidance provision has found that Parliament's intention for the GAAR was consistent with the principle that tax should apply uniformly to all cases that are economically similar. Given that the whole interpretative exercise is to work out whether the GAAR should apply, and that the GAAR embodies this first principle, then in hard cases where the scope of the relevant specific provision relied on is uncertain, this principle should guide interpretation. The purpose of the avoidance provision itself is consistent with the first principle. If it is not possible to rely upon this principle when the scope of the provision that would otherwise be used to determine the appropriate scope of the GAAR in the particular context of the

${ }^{157}$ Elmiger and Another v Commissioner of Inland Revenue [1966] NZLR 683 (SC) at 687.

${ }_{158}$ Elmiger and Another $v$ Commissioner of Inland Revenue [1967] NZLR 161 (CA).

${ }^{159}$ At 4194. 
case is not clear, then the avoidance provision would be given less emphasis than other provisions of the Act. Applying the first principle in cases where the scope of the specific provision relied upon is uncertain allows the court to make reasonable assumptions about Parliament's intention for specific provisions, in the context of an Income Tax Act which has a general antiavoidance rule specifically incorporating this principle.

In the Supreme Court's decision in Ben Nevis, the majority set out a list of factors that would be important to look at when the court was assessing whether there was tax avoidance. The focus on these factors is consistent with the first principle identified in this essay, as they point to the existence of a transaction that is not economically similar to those to which it is purporting to be taxed in the same way. This indicates that where the purpose of a specific provision is not easily discernible, and the decision is a hard case, the court may rely on the factors identified by the Supreme Court and based on the first identified principle. As Elliffe and Cameron put it: ${ }^{160}$

Parliament's purpose in enacting specific provisions is axiomatically targeted at the most commonplace and conventional issues which arise, anything that indicates an unusual or contrived application of a provision is also likely to indicate that the provision was not used in the way Parliament thought it would be. If enough of these abnormalities are present, and are also accompanied by tax advantages, then it is a fair conclusion that the use is outside Parliamentary contemplation.

\section{Conclusion}

Jurisprudential scholars seek to provide a theory of law that best reflects the reality of the legal system. Part of this must include a hypothesis about how judges reach decisions in cases. The best way to evaluate the strength of each jurisprudential approach to decision-making is by applying the theory to cases and assessing whether the theory reflects what seems to have happened in that case. This essay has analysed whether HLA Hart, Ronald Dworkin, or critical legal theorists provide a better theory of how cases are decided in an area of law that is notoriously difficult and uncertain; that is, the application of the general anti-avoidance rule in s BG 1 of the Income

35 Tax Act 2007. Specifically, this essay has sought to assess whether judicial decision-making in this area is influenced by moral principles.

\footnotetext{
${ }^{160}$ Craig Elliffe and Jess Cameron "The Test for Tax Avoidance in New Zealand: A Judicial Sea Change" (2010) 16 New Zealand Business Law Quarterly 440 at 452.
} 
On the basis of the extra-judicial writings of several Australian and New Zealand judges, the paper adopted the view that judges may appeal to principles as part of their reasoning, but that this would only occur in certain hard cases. After laying out s BG 1 of the Income Tax Act, the paper then identified two possible principles that could be important in tax avoidance cases. The two principles identified were the principle that tax should applying uniformly to cases that are economically similar and the principle that taxpayers are entitled to structure their affairs to pay no more tax than the law requires.

10 The next section of the essay sought to apply these principles to the existing precedent on the avoidance section to try and discern whether any of the precedent had been influenced by the principles. Following the parliamentary contemplation test that the Supreme Court laid down for tax avoidance in Ben Nevis, the paper determined that judges have the ability to apply principles in cases where the intended scope of a specific provision of the Income Tax Act is not clear. Although cases decided prior to this decision seemed to embrace the second identified principle, the parliamentary contemplation test is consistent with the first principle; that tax should apply uniformly to all cases that are economically similar. The

20 Supreme Court's decision in this case can be seen as having been influenced by this principle, because of the gaps in the court's reasoning when laying out this test. However, several of the cases subsequently decided show the court engaging in a more thorough analysis of what was within Parliament's contemplation when it enacted the specific provision. These cases therefore support the conclusion reached on the basis of extrajudicial writing, that judges only apply principles in hard cases. The essay concluded that reliance on the first principle in hard cases is justified because of the purpose of the general anti-avoidance rule.

The evidence of judicial reasoning as shown by New Zealand tax 30 avoidance jurisprudence therefore most strongly supports Hart's theory of judicial decision-making. The judicial application of s BG 1 demonstrates that although judges may rely on moral principles when deciding some cases, the use of these principles is neither as prevalent as critical legal theories would indicate or as central to judicial reasoning as Dworkin's theory claims. 


\section{Bibliography}

\section{Cases}

$1 \quad$ New Zealand

Alesco New Zealand Limited v Commissioner of Inland Revenue [2013]

5 NZCA 40, [2013] 2 NZLR 175.

Ben Nevis Forestry Ventures Ltd \& Others $v$ Commissioner of Inland Revenue [2008] NZSC 115, [2009] 2 NZLR 289.

Challenge Corporation v Commissioner of Inland Revenue [1986] 2 NZLR $513(\mathrm{PC})$.

10 Commissioner of Inland Revenue v BNZ Investments Ltd [2002] 1 NZLR 450.

Commissioner of Inland Revenue v Auckland Harbour Board [2001] 3 NZLR 289 (PC).

Commissioner of Inland Revenue v Mitsubishi Motors New Zealand Ltd 15 [1995] 3 NZLR 513 (PC).

Commissioner of Inland Revenue v Europa Oil (NZ) Ltd [1971] 1 NZLR 641, [1971] AC 760.

Dandelion Investments Ltd v CIR [2003] 1 NZLR 600 (CA).

Elmiger v Commissioner of Inland Revenue [1966] NZLR 638 (CA).

20 Glenharrow Holdings Ltd v Commissioner of Inland Revenue [2008] NZSC 116, [2009] 2 NZLR 359.

Mangin v Commissioner of Inland Revenue [1971] NZLR 591 (PC).

Miller v Commissioner of Inland Revenue [2001] 3 NZLR 316 (PC).

O'Neil v Commissioner of Inland Revenue [2001] UKPC 17, [2001] 3 25 NZLR 316. 
Penny and Hooper v Commissioner of Inland Revenue [2011] NZSC 95 (2011) 25 NZTC 20,073.

Peter v Davison [1999] 2 NZLR 164 (CA).

Timaru Herald Co Ltd v Commissioner of Taxes [1938] NZLR 978 (CA).

5 Westpac Banking Corp v Commissioner of Inland Revenue [2009] NZCA 24, [2009] 2 NZLR 99.

$2 \quad$ Australia

WP Keighery Pty Ltd v Federal Commissioner of Taxation (1957) 100 CLR 66 (HCA).

103 England and Wales

Ayrshire Pullman Motor Servs and DM Ritchie v CIR [1929] 14 TC 754 (HL).

Ensign Tankers Ltd v Stoakes [1992] 2 All ER 275 (HL).

Inland Revenue Commissioner v Duke of Westminster [1936] AC 1 (HL).

15 Latilla v Commissioner of Inland Revenue [1943] 1 All ER 265 (HL).

$4 \quad$ United States

Commissioner v Newman 159 F 2d 848 ( $2^{\text {nd }}$ Cir 1947).

Riggs v Palmer 22 NE 188 (NY 1889).

\section{Legislation}

20 Income Tax Act 2007.

Land and Income Tax Assessment Act 1891.

III Journal Articles

Anthony C Infanti “Tax Equity” (2008) 55 Buffalo Law Review 1191. 
Brian Arnold "Reflections on the Relationship between Statutory Interpretation and Tax Avoidance" (2001) 49 Canadian Tax Journal 1.

Craig Elliffe and Jess Cameron "The Test for Tax Avoidance in New Zealand: A Judicial Sea Change" (2010) 16 New Zealand Business Law 5 Quarterly 440.

DG Hill "A Judicial Perspective on Tax Law Reform" (1998) 72 Australian Law Journal 685.

DG Hill "How is Tax Law to be Understood by Courts?" (2001) The Tax Specialist 226.

10 DG Hill "Great Expectations: What do We Expect from Judges in Tax Cases? (1995) 30 Taxation in Australia 21.

David Lyons "Moral Limits on Dworkin's Theory of Law and Legal Interpretation” (2010) 90 Boston University Law Review 595.

Duncan Kennedy and Karl Klare "Biography of Critical Legal Studies" 15 (1984) 94 Yale Law Journal 461.

Elise G Nalbandian “Notes on Ronald Dworkin's Theory of Law” (2009) 3 Mizan Law Review 370.

Eugene Trombitas "Comment: Trinity Exposed: Does the Emperor Really Have No Clothes or is He Wearing an Unusual Silver Rugby Jersey? The

20 Latest News from the GAAR Front” (2007) 13 NZJTLP 583.

Eugen Trombitas "Tax Reform Issue- No Need for a General AntiAvoidance Provision in the Income Tax Act 1994" (1999) 5 New Zealand Journal of Taxation Law and Policy 121.

EW Thomas "The Evolution from Form to Substance in Tax Law: the 25 Demise of the Dysfunctional 'Metwand'” (2011) 19 Waikato L Rev 17.

Gary Minda “Jurisprudence at Century's End” (1993) 43 Journal of Legal Education 27. 
Harry Ebersohn "Tax Avoidance and the Rule of Law" [2012] NZ L Rev 243.

Henry Ordower "The Culture of Tax Avoidance" (2011) 55 St Louis University Law Journal 47.

5 ILM Richardson “Attitudes to Income Tax Avoidance” (1967) 30 NZJPA 1.

ILM Richardson "The Role of Judges as Policy Makers" (1985) 15 VUWLR 46.

JM Balkin "Taking Ideology Seriously: Ronald Dworkin and the CLS Critique" (1987) 55 UMKC Law Review 392.

10 James Allan "Statutory Interpretation and the Courts" (1999) $18 \mathrm{New}$ Zealand University Law Review 439.

Jinyan Li "Comparative Tax Law and Culture: Tax Transplants and Local Culture: A Comparative Study of the Chinese and Canadian Gaar" (2010) 11 Theoretical Inquiries in Law 655.

15 John A Miller "Indeterminacy, Complexity, and Fairness: Justifying Rule Simplification in the Law of Taxation" (1993) 68 Washington Law Review 1.

John Avery Jones "Tax Law: Rules or Principles?" (1996) 17/3 Fiscal Studies 63.

20 John Braithwaite "Rules and Principles: A Theory of Legal Certainty" (2002) 27 Australian Journal of Legal Philosophy 47.

John Prebble "Why is Tax Law Incomprehensible?" [1994] British Tax Review 380.

Joseph M Dodge "Theories of Tax Justice: Rumination on the Benefit,

25 Partnership, and Ability-to-Pay Principles" (2005) 58 New York University Tax Law Review 399.

Judith Freedman "Defining taxpayer responsibility: in support of a general anti avoidance principle" [2004] BTR 332. 
Karen B Brown, Mary Louise Fellows and Bridget J Crawford "The Past, Present and Future of Critical Tax Theory: A Conversation" (2012) 10 Pittsburgh Tax Review 59.

Ken Kress “Legal Indeterminacy” (1989) 77 CLR 283.

$5 \quad$ Ken Kress "Why No Judge Should Be a Dworkinian Coherentist" (1999) 77 Texas Law Review 1375.

Kent Greenwalt "Discretion and Judicial Decision: the Elusive Quest for the Fetters that Bind Judges” (1975) 75 Columbia Law Review 359.

Malcom James "Humpty-Dumpty's Guide to Tax Law: Rules, Principles and 10 Certainty in Taxation" (2010) 21/7 Critical Perspective on Taxation 573.

Mark Burton "The Rhetoric of Tax Interpretation- Where Talking the Talk is Not Walking the Walk" (2005) 1(3) Journal of the Australasian Tax Teachers Association 1.

Michael A Livingston "Radical Scholars, Conservative Field: Putting

15 Critical Tax Studies into Perspective" (1998) 76 North Carolina Law Review 1791.

Michael Littlewood "Ben Nevis Forestry Ventures Ltd and Others v CIR; Glenharrow Lds $v$ CIR - New Zealand's new Supreme Court and Tax Avoidance [2009] BTR 169.

20 Michael Littlewood "Tax Avoidance, the Rule of Law and the New Zealand Supreme Court" [2011] NZ L Rev 35.

Michael Tushnet "Following the Rules Laid Down: A Critique of Interpretivism and Neutral Principles" (1983) 96 Harvard Law Review 781.

Ofer Raban "The Fallacy of Legal Certainty" (2010) 19/175 Boston 25 University Public Interest Law Journal 1.

Rebecca Prebble and John Prebble "Does the Use of General AntiAvoidance Rules to Combat Tax Avoidance Breach Principles of the Rule 
of Law? A Comparative Study" (2010) 55 Saint Louis University Law Journal 21.

Roberto Mangabeira Unger "The Critical Legal Studies Movement” (1983) 96 Harvard Law Review 561.

5 Ronald Dworkin "The Model of Rules" (1967) 35 The University of Chicago Law Review 14.

Scott J Shapiro “The 'Hart-Dworkin' Debate: A Short Guide for the Perplexed" (2007) University of Michigan Public Law and Legal Theory Working Paper No. 77.

10 Sheila E Foster "Westminster Consigned to the Furnace"(1984) 8 Trent Law Journal 65.

Stefanie A Lindquist and Frank B Cross "Empirically Testing Dworkin's Chain Novel Theory: Studying the Path of Precedent" (2005) 80 NYUL Rev 1156.

15 Steven A Bank "Codifying Judicial Doctrines: No Cure for Rules But More Rules?” (2001) 54 SMU Law Review 37.

Tony Honore "The Dependence of Morality on Law (1993) 13 Oxford Journal of Legal Studies 1.

Valerie Braithwaite "Perceptions of Who's Not Paying Their Fair Share" 20 (2003) 38 Australian Journal of Social Issues 335.

Zoe Prebble and John Prebble "The Morality of Tax Avoidance" (2010) 43 Creighton L Rev 694 at 719-721.

\section{Books and Essays in Books}

Aharon Barak Purposive Interpretation in Law (Princeton University Press, 25 New Jersey, 2005).

Brien Leiter "Legal Realism" in Dennis M Patterson (ed) A Companion to Law and Legal Philosophy (Blackwell Publishers, Oxford 1996) 261. 
EW Thomas The Judicial Process: Realism, Pragmatism, Practical Reasoning and Principles (Cambridge University Press, Cambridge, 2005).

HLA Hat The Concept of Law (2 ${ }^{\text {nd }}$ ed, Clarendon Press, Oxford, 1994).

Liam Murphy and Thomas Nagel The Myth of Ownership: Taxes and

5 Justice (Oxford University Press, New York, 2002).

R Posner The Problems of Jurisprudence (1990).

Ronald Dworkin Law's Empire (Harvard University Press, Cambridge, 1986).

Ronald Dworkin Taking Rights Seriously (Harvard University Press,

10 Cambridge, 1978).

Sir Ivor Richardson "Reducing Tax Avoidance by Changing Structures, Processes and Drafting” in Graeme Stuart Cooper (ed) Tax Avoidance and the Rule of Law (IBDF Publications and the Australian Tax Research Foundation, Amsterdam, 1997) 327.

\section{$15 \quad$ Governmental Publications}

HMRC "Tackling Tax Avoidance" (Issue Briefing, London, September 2012).

Public Rulings Unit Interpretation Statement: Tax Avoidance and the Interpretation of sections BG 1 and GA 1 of the Income Tax Act 2007

20 (Inland Revenue Department, Wellington, 2013).

\section{Seminar and Conference Papers}

GT Pagone "Aspects of Tax Avoidance: Trans-Tasman Observations" (paper presented to the International Fiscal Association Conference, Wellington, March 2011).

25 Hon Justice Michael Kirby "Judging: Reflecting on the Moment of Decision" (paper presented at the $5^{\text {th }}$ National Conference on Reasoning and Decision-Making, Wagga Wagga, 4 December 1998). 
Rakesh Datt Gosai "The Role of the Newton Predication Test in the Tax Avoidance Methodology- the Impact of Recent Cases" (MBus Dissertation, University of Auckland, 2009).

\section{Newspaper Articles}

5 Ben Chur "Let's not get bamboozled by Google in the global tax avoidance debate" The Independent (online ed, UK, 16 May 2013).

Charles Arthur "Google will not oppose clampdown on tax avoidance, Chairman says" The Guardian (online ed, UK, 29 January 2013).

Kevin Rawlinson "Google chiefs could face MPs over tax avoidance

10 schemes" The Independent (online ed, UK, 12 August 2012).

Simon Goodley, Simon Bowers and Simon Rogers "UK urged to reform tax rules over profit moving by global firms" The Guardian (online ed, UK, 16 October 2012).

Time Sculthorpe "Corporate Avoidance 'Undermining' Tax System" The 15 Independent (online ed, UK, 30 July 2013). 